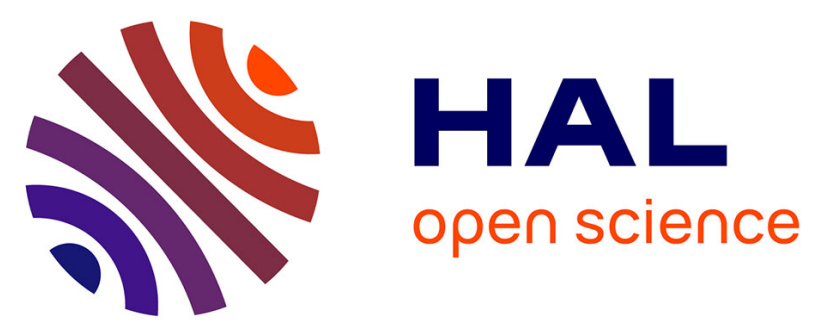

\title{
The key role of the sea urchin Diadema antillarum in controlling macroalgae assemblages throughout the Canary Islands (eastern subtropical Atlantic): an spatio-temporal approach
}

José Carlos Hernández, Sabrina Clemente, Carlos Sangil, Alberto Brito

\section{To cite this version:}

José Carlos Hernández, Sabrina Clemente, Carlos Sangil, Alberto Brito. The key role of the sea urchin Diadema antillarum in controlling macroalgae assemblages throughout the Canary Islands (eastern subtropical Atlantic): an spatio-temporal approach. Marine Environmental Research, 2008, 66 (2), pp.259. 10.1016/j.marenvres.2008.03.002 . hal-00563031

\section{HAL Id: hal-00563031 \\ https://hal.science/hal-00563031}

Submitted on 4 Feb 2011

HAL is a multi-disciplinary open access archive for the deposit and dissemination of scientific research documents, whether they are published or not. The documents may come from teaching and research institutions in France or abroad, or from public or private research centers.
L'archive ouverte pluridisciplinaire HAL, est destinée au dépôt et à la diffusion de documents scientifiques de niveau recherche, publiés ou non, émanant des établissements d'enseignement et de recherche français ou étrangers, des laboratoires publics ou privés. 


\section{Accepted Manuscript}

The key role of the sea urchin Diadema antillarum in controlling macroalgae assemblages throughout the Canary Islands (eastern subtropical Atlantic): an spatio-temporal approach

José Carlos Hernández, Sabrina Clemente, Carlos Sangil, Alberto Brito

PII:

S0141-1136(08)00117-7

DOI:

10.1016/j.marenvres.2008.03.002

Reference:

MERE 3245

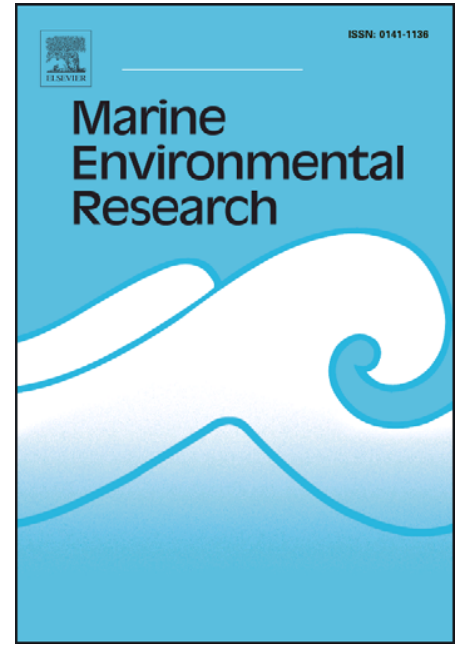

To appear in:

Marine Environmental Research

Received Date:

7 November 2007

Revised Date:

11 March 2008

Accepted Date:

18 March 2008

Please cite this article as: Hernández, J.C., Clemente, S., Sangil, C., Brito, A., The key role of the sea urchin Diadema antillarum in controlling macroalgae assemblages throughout the Canary Islands (eastern subtropical Atlantic): an spatio-temporal approach, Marine Environmental Research (2008), doi: 10.1016/j.marenvres.2008.03.002

This is a PDF file of an unedited manuscript that has been accepted for publication. As a service to our customers we are providing this early version of the manuscript. The manuscript will undergo copyediting, typesetting, and review of the resulting proof before it is published in its final form. Please note that during the production process errors may be discovered which could affect the content, and all legal disclaimers that apply to the journal pertain. 
1 The key role of the sea urchin Diadema aff. antillarum in controlling

2 macroalgae assemblages throughout the Canary Islands (eastern

3 subtropical Atlantic): an spatio-temporal approach

4 José Carlos Hernández ${ }^{12^{*}}$, Sabrina Clemente ${ }^{2}$ Carlos Sangil $^{34}$, Alberto Brito ${ }^{2}$ 5

$7 \quad{ }^{1}$ Villanova University, Dpto. Biology. Villanova, Pennsylvania. USA.

$8 \quad{ }^{2}$ Universidad de La Laguna, Dpto. Biología Animal (Ciencias Marinas). Islas Canarias.

$9 \quad{ }^{3}$ Universidad de La Laguna, Dpto. Biologia Vegetal (Botanica). Islas Canarias.

$10 \quad{ }^{4}$ Reserva Mundial de la Biosfera La Palma. Islas Canarias.

15 *Corresponding author: josecarlos.hernandez@villanova.edu; Villanova University.

16 Pennsylvania. USA. Phone: (610) 519 7348; Fax: (610) 5197863

21 Abstract

22 Diadema aff. antillarum perform a key role in organizing and structuring rocky 23 macroalgae assemblages in the Canary Islands. Densities of $D$. aff. antillarum higher than 
12 individuals $\mathrm{m}^{-2}$ are found to drastically reduce non-crustose macroalgal cover to under

$230 \%$ and wave exposure appears as a major factor determining sea urchin density, which

3 decreases with exposure level. Substrates containing $>20 \%$ sand limit urchin to under

4 one individual $\mathrm{m}^{-2}$, but high relief rocky habitats show higher density. Moreover, several

5 anthropogenic factors (number of islanders and tourists per coastal perimeter, and number

6 of operational fishing boats) were positively correlated with urchin abundance. A trend of

7 increasing urchin density through time was found, although well structured marine

8 systems found at Mar de Las Calmas Marine Protected Area and at the no-take area of La

9 Graciosa Marine Protected Area do not seem to follow this general trend.

11 Key words: Canary Islands, Diadema aff. antillarum, non-crustose macroalgae, spatio-

12 temporal variability, urchin-stable-state, Lobophora-stable-state, MPA

\section{1. Introduction}

15 The importance of herbivorous sea urchins in structuring marine algal assemblages is 16 well known (Lawrence, 1975; Harrold and Pearse, 1987). At moderate population

17 densities, sea urchins may alter plant species composition and promote species diversity 18 through selective feeding (Sammarco, 1982). However, at high densities they can 19 dramatically reduce non-crustose macroalgal beds resulting in the formation of 'sea

20 urchin-dominated barren grounds' (Lawrence, 1975). The occurrence of such areas has

21 been reported along temperate coastlines (North and Pearse, 1970; Andrew, 1993;

22 Scheibling and Hennigar, 1997; Sala et al., 1998; Guidetti 2006) and subtropical

23 coastlines (Brito et al., 1984; Alves et al., 2001; Brito et al., 2004; Hernández, 2006), as

24 well as in tropical regions (Ogden et al., 1973; Sammarco, 1982; McClanahan, 1994). 
1 In the eastern Atlantic oceanic islands, and particularly in the Canary Islands, the

2 density of the genetically differenced 'b-form' of the species Diadema antillarum defined

3 by Lessios et al. (2001) (here called $D$. aff. antillarum) can reach more than 12

4 individuals $\mathrm{m}^{-2}$ and it is spread throughout the entire Archipelago (Brito et al., 1984; Brito

5 et al., 2004; Tuya et al., 2004; Hernández, 2006). Loss of macroalgal beds produces

6 lower species diversity (Herrera, 1998) and loss of habitat suitable for feeding and

7 breeding fish (Brito et al., 2004). Therefore, it is well known that urchin barrens are

8 unproductive habitats, where primary productivity is more than two orders of magnitude

9 lower than at comparable reefs dominated by algal beds in temperate regions (see

10 Chapman, 1981). At this latitude between tropical and temperate waters, macroalgae are

11 the main biological engineers on rocky reefs and no coral reef formations occur.

12 Consequently, high macroalgal cover is a well-known indicator of good benthic

13 conservation status (Hernández et al., 2007a).

14 On temperate and subtropical rocky coasts, subtidal habitats are often characterized

15 by one of two community states: algal bed/kelp forest or sea urchin barren (Lawrence,

16 1975; Sala et al., 1998; Guidetti 2006; Hernández et al., 2007a). Algal beds in the Canary

17 Islands are characterized by brown algae and Lobophora variegata is the most common

18 species. Other widespread algae are the genus Dictyota, Cystoseira and Sargassum

19 (Sansón et al., 2001; Sangil et al., 2006; Hernández et al., 2007a). When urchins are

20 abundant in barrens their intense grazing denudes the seabed of all but encrusting red

21 coralline algae such as Hydrolithon and Neogonolithon, and brown encrusting

22 Pseudolithoderma adriaticum (Sangil et al., 2006). In spite of the high densities of this

23 keystone urchin throughout the Canary Islands, relatively large areas remain with low 24 urchin densities (Brito et al., 1984; Brito et al., 2004; Tuya and Haroun, 2006; Hernández 
1 et al., 2007a), where Lobophora variegata dominates, occupying $80 \%$ of the substrate

2 and reaching $50 \mathrm{~m}$ depth (Tuya and Haroun, 2006; Sangil et al., 2006; Hernández et al., 3 2007a).

4 Occasionally, relevant events such as high recruitment or mass mortality, which alter 5 the adult urchin population, might be noted (Ebert, 1983; Pearse and Hines, 1987;

6 Scheibling and Hennigar, 1997; Lessios, 1988) and these events could be relevant in

7 mediating transitions between alternate states. Mass mortality events have been recorded

8 for different sea urchin species in widespread areas of the world (Pearse et al., 1977;

9 Lessios, 1988; Scheibling and Hennigar, 1997), however no such event has been recorded

10 in the eastern Atlantic, where high densities of urchins and barrens have persisted over

11 the decades (Brito et al., 1984; Hernández, 2006). Experimental urchin exclusions have

12 been performed in the Canary Islands, providing evidence that erect macroalgae have the

13 potential to recolonise encrusting coralline barren areas (Brito et al., 2004). Also shallow

14 rocky bottoms sporadically exposed to storm waves / swell (i.e. high hydrodynamic

15 events) have been found to allow algal growth by removing urchins or restricting the

16 scope of their movement so that they form compliant aggregations (JC. Hernández and S.

17 Clemente personal observation).

18 Habitat complexity is an important factor influencing Diadema grazing (Lee, 2006),

19 as well as for other sea urchin species (Andrew, 1993), since complex habitats provide

20 urchins with refuge from predation (Levitan and Genovese, 1989). The availablility of

21 refuges and the urchins' so called cryptic behavior seems to help promote survival of

22 recruits in complex rocky areas (Levitan and Genovese, 1989) and probably contributes

23 to the high adult population density typically found in these habitats (Hernández et al., 24 2006a, Hernández 2006; Clemente et al., 2007). Gradients in the physical environment 
1 may produce spatial heterogeneity of marine assemblages at different scales simply as a

2 consequence of the space available or of the different physiological tolerances of the

3 species (Levitan and Genovese, 1989; Andrew, 1993). However, few habitat complexity

4 studies have been carried out with urchins in subtidal marine environments (McClanahan,

5 1994; Lee, 2006; Clemente et al., 2007). Since depth, wave exposure and habitat

6 complexity are believed to affect Diadema aff. antillarum distribution and abundance

7 (Alves et al., 2001; Hernández, 2006; Clemente et al., 2007), any interpretation of

8 changes in urchin populations must be made with knowledge of the species' basic

9 variation in relation to these environmental variables.

10 Here we present a medium-term data set, recorded throughout the Canarian

11 Archipielago over seven years and 125 sites that aim to improve the understanding of

12 spatial variation at different scales. This study assesses Diadema aff. antillarum

13 populations, cover of urchin barren vs. macroalgae and habitat-complexity. Variation is

14 studied on different spatial scales (islands and areas of different wave exposure, human

15 pressure, depth, and habitat complexity); as well as on different temporal scales. During

16 the course of the sampling period a strong urchin recruitment event was detected due to

17 noticiable seawater warming during 2003 and 2004 in the Canary Islands (Hernández,

18 2006; Hernández et al., 2006a). A re-sample of study sites was performed after the

19 recruitment event to detect whether the effect of this phenomenon was spread thoughout

20 the Canary Islands' Marine Protected Areas (MPAs) and Highly Fished Areas (HFAs).

\section{2. Material and Methods}

23 2.1. Study site: oceanographic features of the Canary Islands 
$1 \quad$ The Canary Islands are situated between latitude 27.68-29.58 N and longitude 18.28-

$214.58 \mathrm{~W}$ on the eastern border of the North Atlantic Ocean's subtropical gyre. Emerging

3 from the oceanic basin as a result of successive overlays of volcanic material to form an

4 independent set of islands, the Canarian Archipelago comprises seven major islands and

5 four islets. The eastern boundary of the archipelago is separated from the coast of the

6 African mainland by a distance of $90 \mathrm{~km}$ and it extends about $400 \mathrm{~km}$ further west. This

7 geographical location between the cool, nutrient-rich water from the north-west African

8 coastal upwelling, and the warmer, nutrient-poor open ocean waters, means the Canary

9 Islands are considered a 'Coastal Transition Zone' (Barton et al., 1998). In addition, the

10 archipelago itself acts as an obstacle to both the Canary Current, which flows NNE to

11 SSW, as well as to the Trade Winds; thus giving rise to a variety of mesoscale

12 oceanographic phenomena that have strong implications for the productivity of the region

13 (Barton et al, 1998). This particular geographical situation creates an oceanographic

14 gradient across the archipelago, where differences in sea water temperature $\left(\approx 2^{\circ} \mathrm{C}\right)$,

15 nutrients and primary productivity are found between its eastern and western boundaries

16 (Barton et al., 1998). Therefore, the islands' marine assemblages consist of a combination

17 of tropical, subtropical and temperate species which varies according to its location

18 within the oceanographic gradient (Sansón et al., 2001; Brito et al., 2001).

19 Exposure to wave action is a strong force in segregating urchin species (Tuya et al.,

20 2007). The shape of the island and its orientation against the waves creates different

21 degrees of wave exposure along the different coastlines. The normal wave pattern

22 consists of sea waves from NNE, which have an annual average height of $1.4 \mathrm{~m}$ and a

23 frequency of $9.5 \mathrm{~s}$. NNE swells are abundant throughout the year and more frequent from 
1 autumn to spring, also associated with NNE and NE winds. Otherwise swells originating

2 in the Northern Atlantic become more frequent between October and March and

3 approach the islands from NNW and NW, with an annual wave height between 2-3 $\mathrm{m}$ and

4 a frequency of $18 \mathrm{~s}$ (Yanes et al., 2006). According to the different spatial behavior of

5 swells, differences in terms of average annual height and frequency of waves between the

6 northern, western and eastern-southeastern coasts are found. Eastern, southeastern and

7 southern coasts of the islands are sheltered from NNW-NW strong swells and face waves

8 that are on average smaller than those received by northern and western coastlines, which

9 are exposed to non-local swells (Yanes et al., 2006).

\section{$11 \quad$ 2.2. Sampling methods: sea urchins and algal assemblages}

12 At each site the belt transect method was used to count all Diadema aff. antillarum

13 individuals thus providing estimates of sea urchin population density. Transects of $10 \times 2$

$14 \mathrm{~m}$, suitable for the benthic communities investigated (Hernández et al., 2007a), were used

15 with at least 8 replicates per site. Transects were run parallel to the coastline using a

16 metric tape at depths of 0.5-25 m, with a minumun distance between replicates of $10 \mathrm{~m}$.

17 Percentages of non-crustose macroalgae and barren cover were estimated in situ by

18 randomly placing 3-5 quadrats per transect. Barren cover was defined as total surface

19 covered by crustose macroalgae and bare rock (modified from Guidetti, 2006). Dominant

20 algal assemblage was recorded in all sites considering five morpho-functional groups

21 (Guidetti, 2006): (a) algal turf; (b) unbranched-erect macroalgae; (c) branched-erect

22 macroalgae; (d) calcified-erect macroalgae and (e) crustose macroalgae (Table 1). These

23 groupings facilitate the ecological interpretation of algal assemblages influenced by $D$.

24 aff. antillarum. 
$2 \quad$ 2.3. Sampling design and data analysis

$3 \quad$ 2.3.1. Influence of sea urchin population density on algal assemblages

4 The influence of urchin populations on algae assemblages was assessed using data 5 from 125 sites around the Canary Islands (Fig. 1; see table 1 in Suplementary materials)

6 over the period 2001-2006. Log-linear relationships between urchin density (individuals

$7 \mathrm{~m}^{-2}$ ) and non-crustose macroalgal cover (\%) were performed using SPSS-14 statistical 8 package.

9 2.3.2. Large scale spatial variation: influence of wave exposure and human pressure in 10 sea urchin archipelagic distribution

11 To assess spatial variation over a scale of kilometers, a total of 125 sites were 12 sampled between 2001-2006 throughout the entire archipelago (Fig.1; see table 1 in

13 Suplementary materials). Sites were chosen from two different wave exposure levels.

14 Different degrees of exposure can be found on an island due to its local topography,

15 which can be simplified into two main levels, as described in section 2.1 following Yanes 16 et al. (2006):

17 - High exposure: sites located on the north or northwest side of the islands and islets, 18 affected by trade winds and swells from NNE-NE and often by NNW-NW swells, as well 19 as sites only affected by NNW-NW swells (see table 1 in Supplementary materials).

20 - Low exposure: sites located on the east, south or southeast side of the islands and 21 islets normally affected by trade winds waves and swells from NNE-NE and not by 22 NNW-NW swells (see table 1 in Supplementary materials).

23 In order to contrast sea urchin density and barren cover among islands and degrees of 24 exposure to wave action, we performed distance-based permutational ANOVAs 
1 (Anderson, 2001). A three way design was performed when analysing urchin density and

2 barren cover, in which 'Island' (I) was treated as a fixed factor with seven levels;

3 'Exposure' (E) as a fixed factor with two levels and 'Site' (S) as a random factor nested

4 in the interaction ' $\mathrm{I} x \mathrm{E}$ '. All analyses were based on euclidean distances of the original

5 raw data, with all p-values obtained using 4.999 permutations of the appropriate

6 exchangeable units (Anderson, 2001). Significant terms in the full model were examined

7 individually using appropriate a posteriori pairwise comparisons. The software PRIMER

86 \& PERMANOVA+ was used to perform these analyses.

9 Relationships between sea urchin density and factors that define human and fishing

10 pressure (number of islanders and tourists per island perimeter, and number of fishing

11 boats) were analysed. Logarithmic and linear models were performed using the SPSS

1214.0 statistical package. Information on human and fishing pressure in the Canary Islands

13 was obtained from Gobierno de Canarias (www.gobcan.es), National Spanish Network of

14 Marine Protected Areas (www.mapya.es/rmarinas/) and Bas et al. (1995); data previously

15 used by Tuya et al. (2006a). Similar data have been used by other authors to provide a

16 useful depiction of anthropogenic pressure and resource exploitation (Hawkins and

17 Roberts, 2004). Data from Gran Canaria Island were not included in the regression due to

18 proximity of sampling sites (see Fig. 1).

19 2.3.3. Medium-small scale spatial variation: influence of depth, sedimentation,

20 topographic relief, slope and substratum diversity

21 To assess spatial variation at a scale of meters, depth and four main habitat22 complexity variables were identified: 
1 -Sedimentation (Díez et al., 2003): estimated as the percentage of rock covered by

2 sand at each transect and asignated to categories of (1) $0 \%$; (2) $1-10 \%$; (3) $10-20 \%$; and

3 (4) more than $20 \%$.

4 -Topographic relief (McClanahan, 1994): visually estimated at each transect,

5 considering contour height in relation to linear surface area, as (1) flat surface; (2) less

6 than $1 \mathrm{~m}$; (3) between 1-3 m; and (4) high relief, more than $3 \mathrm{~m}$.

$7 \quad$-Slope (Díez et al., 2003): measured at each transect as the inclination of the substrate

8 in degrees, using an angle meter with a weight as a pendulum, and then assigned to the

9 categories $(1) 0^{\circ}$; (2) from $0^{\circ}$ to $45^{\circ}$; (3) more than $45^{\circ}$; and (4) $90^{\circ}$.

10 -Substratum diversity (Gratwicke and Speight, 2005): considered as the substrate type

11 or combination of substrates visually identified at belt transects. We categorized them as:

12 (1) bed rock; (2) boulders from 5-100 cm; (3) a combination of bed rock and boulders.

13 The influence of each habitat-complexity variable on Diadema aff. antillarum density

14 and barren cover was tested using field data collected in 1112 belt transects performed

15 throughout the entire Canarian Archipelago (Fig. 1). We performed three way distance-

16 based permutational ANOVAs (Anderson, 2001), in which 'Island' was treated as a fixed

17 factor with seven levels. Habitat-complexity variables were treated as fixed factors with

18 four levels each for 'Sand' (Sa), 'Topographic relief' (TR) and 'Slope' (Sl) and three

19 levels for 'Substrate diversity' (SD). 'Site' was treated as a random factor nested within

20 the interaction 'Island $\mathrm{x}$ habitat-complexity variable'.

21 2.3.4. Temporal variation: effects of sea urchin population expansion throughout the

22 Archipelago (MPAs vs HFA)

23 To temporally monitor sea urchin density, three sites were chosen (Fig. 1; see table 1

24 in Supplemetary materials). Abades was the most sampled site with three years of 
1 monthly sampling from February 2002 to February 2005, and some additional seasonal

2 sampling in 2005-2006. Masca was sampled monthly from February 2002 to March 2003

3 and Boca Cangrejo from January 2004 to February 2005. In Boca Cangrejo, further data

4 were collected in selected months of 2005, as well as seasonally in 2006. Year to year

5 variations in urchin density and barren cover were tested, between Abades and Masca

6 (2002 to 2003) and between Abades and Boca Cangrejo (2004 and 2005), with the factor

7 'Year' (Y) treated as a fixed factor and 'Site' (S) as a random factor.

8 Sea urchin population outbreaks were detected at two sites in Tenerife (Abades and

9 Boca Cangrejo) during 2004 and 2005. These two instances of proliferation can both be

10 related to increases in water temperature (Hernández, 2006; Hernández et al., 2006a) and

11 provided the opportunity to study how the response of urchin populations varied across

12 the Canarian Archipelago. A total of 24 sites, for which previous data were available,

13 were revisited during 2006 to assess the effect of the detected outbreak in different areas:

147 sites in Mar de Las Calmas MPA (E1 Hierro), 11 sites in Tenerife HFA and 6 sites in La

15 Graciosa MPA (Lanzarote and northern islets) (Fig. 1; see table 1 in Suplementary

16 materials). Seasonal and spatial variations in adult density and barren cover were

17 analyzed using a three way Permutational ANOVA. The orthogonal factor 'Outbreak

18 event' (O) was treated as a fixed with two levels of variation: (1) before and (2) after the

19 event; Island (I) as a fixed factor with three levels: (1) Mar de Las Calmas-MPA, (2)

20 Tenerife-HFA and (3) La Graciosa-MPA; and 'Site' (S) as a random factor nested within

21 'Island' with 24 levels. While Mar de Las Calmas-MPA had large areas dominated by

22 Lobophora variegata before the outbreak, La Graciosa-MPA and Tenerife-HFA showed

23 dense barrens of Diadema aff. antillarum (Brito et al., 2004; Hernández et al., 2007a). 

14 individuals $\mathrm{m}^{-2}$ (Fig. 2).

\section{Results} Islands

\subsection{Influence of sea urchin populations on algal assemblages throughout the Canary}

A highly significant log-linear relationship was detected between sea urchin density and non-crustose macroalgal cover (Fig. 2). The scatter plot of sea urchin density versus non-crustose macroalgal cover showed more variability in percentage of algal cover at the lowest urchin densities, in which higher variability in the dominant morphofunctional algal group also occurs. At intermediate densities this variability decreased sharply and at a threshold density of about 4 individuals $\mathrm{m}^{-2}$ non-crustose macroalgal cover remains below $30 \%$, with crustose macroalgae clearly the dominant algal group (Fig. 2). In general, when urchin densities exceed 4.5 individual $\mathrm{m}^{-2}$, turf, unbranchederect and branched-erect macroalgae did not appear as dominant (Fig. 2). Calcified-erect macroalgae only appeared as the dominant algae when urchin densities were below 6.5

\subsection{Spatial variation at large scale: effect of wave exposure on sea urchin populations} High variability in Diadema aff. antillarum population density throughout the Canarian Archipelago was detected. Permutational ANOVA results revealed a highly significant effect of the main factor 'Island' and to a lesser extent of the factor 'Exposure' (Table 2A). A posteriori pairwise analyses showed that the maximum sea urchin densities were recorded at Tenerife island, which differs significantly from the medium densities registered in Lanzarote-La Graciosa $(\mathrm{t}=2.42, \mathrm{p}<0.05)$, La Gomera $(\mathrm{t}=3.14, \mathrm{p}<0.01)$, La

23 Palma $(\mathrm{t}=4.01, \mathrm{p}<0.01)$, Fuerteventura $(\mathrm{t}=3.83, \mathrm{p}<0.01)$ and Gran Canaria $(\mathrm{t}=4.16$, $4 \mathrm{p}<0.01)$. El Hierro comprised the lowest densities, which were significantly different 
1 from those recorded on the other islands $(\mathrm{t}=8.07, \mathrm{p}<0.01, \mathrm{t}=5.44, \mathrm{p}<0.01, \mathrm{t}=8.36$,

$2 \mathrm{p}<0.01, \mathrm{t}=4.09, \mathrm{p}<0.01, \mathrm{t}=1.94, \mathrm{p}<0.05$ and $\mathrm{t}=6.64$ respectively, $\mathrm{p}<0.01)\left(\right.$ Fig. $\left.3 \mathrm{~A}_{1}\right)$.

3 Results concerning the factor 'Exposure' show that sites with high levels of exposure to

4 wave action maintained significantly lower $D$. aff. antillarum densities $(2.27 \pm 0.14$

5 individuals $\left.\mathrm{m}^{-2}\right)$ than those less exposed $\left(3.49 \pm 0.12\right.$ individuals $\left.\mathrm{m}^{-2}\right)\left(\right.$ Fig. $\left.3 \mathrm{~A}_{2}\right)$. There

6 were also differences in urchin densities between sites at each island (Table 2A).

7 The assessment of barren ground cover across the Archipelago showed a significant

8 interaction of factors 'Island $\mathrm{x}$ Exposure' (Table 2B). Barren ground cover differed

9 depending on level of exposure to wave action in relation to each island considered, as

10 shown by a posteriori pairwise analyses. The only island for which differences were

11 obtained was Tenerife, where barren cover was found to be significantly higher at less

12 exposed sites $(\mathrm{t}=2.92, \mathrm{p}<0.01)$ (Fig. 3B). No significant differences were obtained at El

13 Hierro $(\mathrm{t}=1.25, \mathrm{p}=0.23)$, La Palma $\mathrm{t}=0.10, \mathrm{p}=0.93)$, La Gomera $(\mathrm{t}=0.99, \mathrm{p}=0.34)$,

14 Gran Canaria $(\mathrm{t}=0.43, \mathrm{p}=0.68)$, Fuerteventura $(\mathrm{t}=1.90, \mathrm{p}=0.09)$ and Lanzarote-La

15 Graciosa $(t=1.60, p=0.13)$ (Fig. 3B). On the other hand, differences at the scale of

16 factor 'Site (Island)' were also significant (Table 2B), differing in the \% of barren ground

17 cover between sites at each island.

19 3.3. Spatial variation at large scale: interaction between sea urchin and humans

20 A significant log-linear relationship was detected between sea urchin density and 21 number of islander's resident along the coastal perimeter (Fig. 4A). The scatter plot of

22 sea urchin density versus number of islanders per coastal perimeter showed Tenerife's

23 more populated coastal perimeter also had the highest sea urchin density. A low 24 significant linear relationship was detected between sea urchin density and number of 
1 tourist per coastal perimeter (Fig. 4B), and a low significant log-linear relationship was

2 found between sea urchin density and number of fishing boats (Fig. 4C).

4 3.4. Spatial variation at medium-small scale

5 3.4.1. Depth

6 When assessing the variability of $D$. aff. antillarum density with depth, the scatter

7 plot showed higher variability in urchin density at shallower depths $(<7 \mathrm{~m})$ for those sites

8 less exposed to wave action (Fig. 5). At highly exposed sites urchin density hardly varied

9 in shallow water but variability was found to increase with depth (Fig. 5). The critical

10 threshold of 4 individuals $\mathrm{m}^{-2}$ previously reported to drastically reduce non-crustose

11 macroalgal cover, was not reached at highly exposed sites at depths less than about $7 \mathrm{~m}$,

12 while at less exposed sites this density is common in shallower water $(\sim 3 \mathrm{~m})$ (Fig. 5).

\section{3.4.2. Sedimentation}

14 Permutational ANOVA analysis showed a significant effect of the factor

15 'Sedimentation' over $D$. aff. antillarum densities, as well as of the factor 'Island' (Table

$163 \mathrm{~A})$. A posteriori pairwise analyses showed urchin density to be significantly lower on

17 substrates where sand was $>20 \%$ compared to those without any sand $(\mathrm{t}=2.82, \mathrm{p}<0.01)$,

$181-10 \%(\mathrm{t}=2.13, \mathrm{p}<0.05)$ and $10-20 \%(\mathrm{t}=1.87, \mathrm{p}<0.05)$ (Fig. 6A). Variations at the

19 scale of 'Site (Island x Sedimentation)' were obtained (Table 3A), differing urchin

20 density between sites at each island in relation to the sedimentation level considered.

21 Analyses showed no significant effect of either 'Sedimentation' or the interaction of

22 factors 'Island $\mathrm{x}$ Sedimentation' on barren cover, although differences at the level of

23 'Island' and 'Site (Island x Sedimentation)' were still found (Fig. 6A; Table 3B).

\section{3.4.3. Topographic relief}


1 Permutational ANOVA analysis showed both 'Island' and 'Topographic relief' (TR)

2 had highly significant effects on $D$. aff. antillarum density (Table 4A). A posteriori

3 pairwise analyses showed urchin density to be significantly higher at the highest TR level

4 (4) than in habitats with lower TR: level $1(\mathrm{t}=5.17, \mathrm{p}<0.01), 2(\mathrm{t}=4.67, \mathrm{p}<0.01)$ and $3(\mathrm{t}$

$5=3.15, \mathrm{p}<0.01$ ) (Fig. 6B). Moreover, differences with regard to the factor 'Site (Island $\mathrm{x}$

6 Rugosity)' were significant (Table 4A), meaning that urchin density differed between

7 sites at each island in relation to the rugosity level.

8 When analysing barren cover, a significant effect of TR and highly significant effects

9 of factors 'Island' and 'Site (Island x TR)' were obtained (Table 4B). A posteriori tests

10 showed significant differences in percentage of barren cover between sites within the

11 highest TR (4); which had a higher percentage of barren cover than at lower levels $1(\mathrm{t}=$

$121.87, \mathrm{p}<0.05), 2(\mathrm{t}=3.16, \mathrm{p}<0.01)$ and $3(\mathrm{t}=1.92, \mathrm{p}<0.05)($ Fig. 6B).

13 3.4.4. Slope

14 Permutational ANOVA analyses showed no significant effect of 'Slope' or the

15 interaction 'Island x Slope' on D. aff. antillarum density and on percentage of barren 16 cover. However, differences at the level of 'Island' and 'Site (Island x Sedimentation)'

17 were always found to be significant (see table 2 in Suplementary material).

\section{3.4.5. Substrate diversity}

19 There were no significant effects of factor 'Substrate' or even of the interaction

20 'Island x Substrate' on urchin density and barren cover, although differences at the levels

21 of 'Island' and 'Site (Island $\mathrm{x}$ Sedimentation)' were significant (see table 3 in

22 Supplementary material). 


\subsubsection{Medium term monitoring}

Sea urchin densities exceed 4 individuals $\mathrm{m}^{-2}$ at all studied sites and sampling periods, with higher values at Abades than at Masca and Boca Cangrejo. While the range of densites registered at each site was more stable from 2002 to 2005, Abades and Boca Cangrejo sites showed a trend of substantial increase of densities during 2005 and 2006 (Fig. 7A). Analyses comparing urchin density over the studied years showed significant effects of both main factors 'Year' and 'Site' (Table 5A). A posteriori tests showed that densities recorded in 2002 and $2004(\mathrm{t}=0.37, \mathrm{p}=0.81)$ differed ( 02 vs. $05: \mathrm{t}=23.32, \mathrm{p}<$ $0.05 ; 02$ vs. $06: \mathrm{t}=24.25, \mathrm{p}<0.05 ; 04$ vs. $05: \mathrm{t}=39.74, \mathrm{p}<0.05$ and 04 vs. $06: \mathrm{t}=$ $368.45, \mathrm{p}<0.01)$ from those collected in 2005 and 2006 at all sites $(\mathrm{t}=4.84, \mathrm{p}=0.13)$ (Fig. 7A).

Percentages of barren cover remained high (above $80 \%$ ) over the whole duration of the study with slight variability between sites (Fig. 7B). Analyses comparing this variable over the years showed significant effects of the interaction 'Year x Site' (Table 5B), with percentages differing in relation to the site (Table 5B).

\subsubsection{Analysis of the sea urchin outbreak}

A two-way Permutational ANOVA was used to assess the seasonal and spatial variations of a population 'outbreak' across the Canarian Archipelago. A significant effect of the interaction 'Outbreak event $\mathrm{x}$ Island' on urchin density was obtained (Table $6 \mathrm{~A})$, differing urchin density before and after the reported event in relation to the island considered (Fig. 8A and 9). A posteriori pairwise analyses of this interaction showed densities recorded before compared to after the event were significantly different at El Hierro where urchin density was lower after the event $(\mathrm{t}=4.79, \mathrm{p}<0.01)$, and at Tenerife where urchin density was found to be higher after the event $(\mathrm{t}=4.21, \mathrm{p}<0.01)$, (Figs. 8A 
1 and 9). In La Graciosa there was an increase in urchin density but the a posteriori test did

2 not show the difference to be significant $(\mathrm{t}=1.79, \mathrm{p}=0.14)$ (Figs. 8A and 9).

3 Similarly, in terms of percentage barren cover, there was shown to be a significant

4 effect of the main factor 'Island' as well as of the interaction of factors 'Outbreak event $\mathrm{x}$

5 Site (Island)' (Table 6B), with these variables differing before and after the reported

6 event in relation to the site considered at each island (Fig. 8B).

\section{Discussion}

9 4.1. Influence of urchin populations on macroalgal assemblages throughout the Canary

10 Islands: barren ground state definition

11 Diadema aff. antillarum exhibits a key role in controlling fleshy macroalgae on rocky

12 bottoms of the eastern Atlantic Islands (Madeira, Salvajes, Canary Islands) as

13 demonstrated by various authors in recent years (Alves et al., 2001; Brito et al., 2004;

14 Tuya et al., 2004; Hernández et al., 2007a). However, the urchin barren state was noticed

15 long before in the Canary Islands (Brito et al., 1984).

16 In general, at a density of 4 individuals $\mathrm{m}^{-2}$, non-crustose percentage cover of

17 macroalgal assemblages is drastically reduced to around $30 \%$ or less. Nevertheless, the

18 effect over algal cover differs depending on the algal group in question. While crustose

19 macroalgae maintain a high percentage cover with increasing urchin density, others such

20 as branched and unbranched macroalgae virtually disappear at densities around 4

21 individuals $\mathrm{m}^{-2}$. Filamentous algae and articulate coralline assemblages have been seen to

22 maintain a low presence on densely populated barrens. At an urchin density above 2

23 individuals $\mathrm{m}^{-2}$, non-crustose macroalgal cover is drastically reduced below $15 \%$, and at

24 densities above 4 individuals $\mathrm{m}^{-2}$ it barely exceeds $10 \%$. Even though there is spatial 
1 variability in this general pattern, due to the particular environmental conditions that may

2 favor recruitment and growth of algae (Sansón et al., 2001; Tuya and Haroun, 2006;

3 Sangil et al., 2006), we consider a threshold density of 2 individuals $\mathrm{m}^{-2}$ in a rocky

4 subtidal habitat to represent an urchin barren ground in the Canary Islands. When urchin

5 density exceeds 4 individuals $\mathrm{m}^{-2}$ it could be considered a degraded urchin barren where

6 non-macroalgae beds can develop. Definitions of these thresholds are useful with regard

7 to conservation strategies, as they allow one to distinguish between habitats with urchins

8 simply present and habitats dominated by urchins which could be considered 'undesired

9 states' and have high resistance to restoration (Hernández et al., 2007a). Barren grounds

10 are continuously invaded by algal spores and propagules but intensive grazing by urchins

11 prevents the establishment of most species and maintains any existing macroalgal

12 assemblage in the early succession stage (Brito et al., 2004). Once a habitat is in the

13 barren state, urchins can survive indefinitely by feeding upon animals, coralline algae,

14 microbial films and drift algae (Hernández et al., 2007b).

15 Compared to typical urchin barrens elsewhere in the world (Chapman 1981; Pearse 16 and Hines 1987; Valentine and Johnson, 2005; Guidetti and Dulčić, 2007), barrens in the

17 Canary Islands appear to be maintained by sea urchins at relatively low densities $(\approx 2$

18 individuals $\mathrm{m}^{-2}$ ). Their movement rate and food consumption rate, which involves grazing

19 large areas of rocky substrate at night, could explain these differences. Through its

20 movements and potentially large grazing grounds, Diadema antillarum can efficiently

21 remove its preferred macroalgal species (Carpenter, 1981). In the oligotrophic Caribbean

22 waters mean urchin densities around 10 individuals $\mathrm{m}^{-2}$ were recorded (Bak et al., 1984;

23 see review in Lessios, 1988) and high abundances were noticed before a mass mortality 24 event (Lessios, 1988). In similar oligotrophic conditions, the limited 'nutrient' resources 
1 provided by waters surrounding the Canary Islands are not enough to maintain high

2 urchin populations, but, as already stated, a relatively low urchin density is able to

3 maintain a barren habitat. Despite limited nutrient supply in the Caribbean, the high

4 abundance of urchins recorded in the area could be due to the increased habitat

5 complexity created by corals which benefit the urchins (Lee, 2006), as also shown in this

6 study in the case on rocky bottoms (see section 4.3 below).

8 4.2. Actual status of Diadema aff. antillarum populations throughout the Archipelago:

9 influence of human pressure and wave exposure

10 Diadema aff. antillarum is spread across the entire Canarian Archipelago, with

11 noticeable spatial variation in density. However, there is no a clear pattern to show

12 oceanographic gradient affecting species distribution. Other authors have postulated that

13 the extent of overfishing at each particular island determines urchin density (Tuya et al.,

14 2004), and overfishing is thought to be a general problem in the Canaries (Brito et al.,

15 1984; Falcón et al., 1996). The highest urchin densities were recorded in Tenerife, the

16 island that supports high number of locals and tourists, denoting more pollution, more

17 fishing pressure and less conservation of the marine environment. El Hierro, the smallest

18 island, has less residents and tourists (Bortone et al., 1991), less intense fisheries, as well

19 as MPA-conservation policies, and therefore provides a higher level of conservation

20 along its coastline (Hernández et al, 2007a). Gran Canaria showed less dense urchin

21 populations, as would be expected considering the human pressure and high level of

22 fishing effort (Bortone et al., 1991; Bas et al., 1995; Tuya et al., 2006a). Although,

23 skewed sampling distribution in this island may be underestimating the real density. 
1 Spatial variation and patchiness found at each island illustrate that other

2 environmental factors are controlling and influencing sea urchin abundance. Of particular

3 importance is the existence of great water depths very close to the breakers. For example,

4 in El Hierro Island, $50 \mathrm{~m}$ offshore the water is $50 \mathrm{~m}$ deep, therefore waves conserve much

5 of their initial energy up to the breakpoint (Yanes et al., 2006). Consequently, NW-NNW

6 sea swells seems to affect urchin populations more than trade winds, and the incidence of

7 storms determines their distribution as waves induce dislodgement, particularly in this

8 species (Tuya et al., 2007). Urchin density also tends to be higher along sheltered

9 coastlines compared to exposed ones, as previously noted in the Caribbean (Debrot and

10 Nagelkerken, 2006). Consequently, general urchin distribution is controlled by wave

11 force and island slope that affects the energy of the wave. Protected coasts have calmer

12 waters that promote urchin larvae retention and increased water temperature that

13 enhances larval metamorphosis and settlement (Hernández, 2006), while at exposed sites

14 larvae tend to get washed away. Such has been noticed for Strongylocentrotus purpuratus

15 in capes and headlands due to high upwelling flow (Ebert and Russell, 1988).

17 4.3. Does habitat complexity affect sea urchin distribution?

18 Different patterns of variation in urchin populations and macroalgae have been

19 reported at the studied areas with regard to depth. Areas with higher hydrodynamics show

20 greater urchin density in the deeper band between 14-20 m water depth. In less exposed

21 areas denser populations appear between 5-11 m. Depth limits recorded here agree with

22 the theoretical model described by Tuya et al. (2007) who performed hydrodynamic

23 experiments in a flow tank to estimate depth-limits beyond which urchin species can not

24 withstand unidirectional waves. Density accumulation below certain depth limit could be 
1 explained as a migratory strategy of urchins which tend to form fronts just below the

2 algal stand, as has been observed in Strongylocentrotus droebachiensis (Lauzon-Guay

3 and Scheibling, 2007). Along sheltered coasts, algal beds exist only at the shallower level

4 and urchin biomass accumulates in this band where more food is available. However,

5 along exposed coasts high urchin densities appear at greater depth but just below the algal

6 stand. Hydrodynamics allows algal growth by removing Diadema by dislodgement,

7 preventing its grazing activity (Tuya et al., 2007) or limiting their movement. Wave

8 action is therefore an important force limiting urchin grazing and density, and is the

9 mechanism that maintains shallow water algal stands throughout the Canary Islands

10 (Tuya and Haroun, 2006) and other places (Alves et al., 2001; Lauzon-Guay and

11 Scheibling, 2007).

12 Another important factor limiting urchin density is the percentage of sand or

13 sedimentation, as other studies have demonstrated on rocky reef organisms (Airoldi

14 2003). Levels above 10-20\% sand keep urchin densities below 2 individuals $\mathrm{m}^{-2}$. The

15 combined effects of water motion and sediment scouring the substrate can weaken the

16 attachment between urchin and substrate as well as impairing their mobility.

17 Surveys revealed that substrate topographic relief and Diadema density were

18 positively related, as has been noted in the Caribbean (Lee, 2006). Increasing habitat

19 complexity by adding physical structure significantly increased the proportion of urchins,

20 while low habitat complexity was found to permit macroalgal-dominated reefs. High

21 topographic relief provides more suitable habitat on which urchins can reside

22 (Hernández, 2006) and these areas can support denser populations, as noted by Clemente

23 et al. (2007) in barren grounds of Tenerife. Future conservation strategies need to

24 consider habitat complexity, since certain habitats are potentially occupied by higher 
1 numbers of urchins and are likely to present high resistance to restoration due to positive

2 feedback mechanisms that stabilize the system (Knowlton, 2004). Furthermore, it is

3 important to consider that human actions along the coast such as the construction of piers,

4 harbours, jetties and artificial reefs, could act as a potential stepping stone for spread of

5 this urchin. Artificial substrates such as these offer high relief habitat space and a

6 sheltered area for larval settlement, which means they can encourage and support large

7 urchin populations (Herrera, 1998).

9 4.4. Persistence of algal / urchin states and influence of recent urchin demographic 10 outbreak throughout the Canary Islands

11 'Barren ground' and 'Lobophora bed' states exhibit a high degree of persistence and 12 stability in the Canary Islands (Brito et al., 1984; Bortone et al., 1991; Hernández et al., 13 2007a). However, the area occupied by each system clearly differs. Barren grounds are 14 spread over the entire archipelago and can reach $50 \mathrm{~m}$ depth, whereas Lobophora beds 15 only appear in large areas of rocky bottom $(0-60 \mathrm{~m})$ in El Hierro and southwestern La

16 Palma, and in the rest of the archipelago they are restricted to shallow areas where wave 17 action keeps urchin grazing activity at a very low intensity.

18 The monthly variation in urchin density in shallow waters found by Tuya et al.

19 (2006b) agrees with our results in which wave exposure is related to adult density.

20 However, our depth range study shows that this variation only occurs in shallow waters.

21 The persistence of the high urchin densities even where little food remains may be down

22 to a continuous larval supply (Hernández et al., 2006b) and the absence of urchin's main

23 predators. Overfishing creates a trophic cascade effect which allows urchins to flourish, 24 as seen in Tenerife (Clemente et al., 2007). In addition, enrichment of coastal waters with 
1 sewage effluent due to high human activity (amino acid enrichment) adds significantly to

2 the nutrition received by urchins (North and Pearse, 1970), and recent sea water warming

3 may have also increased Diadema larval settlement (Hernández et al., 2006a; Hernández,

4 2006) by increasing larvae develop. Other areas around the world have shown

5 continuation of barren states (Chapman, 1981; Valentine and Johnson, 2005) although

6 mass mortality events have also occurred (Lessios, 1988; Scheibling and Hennigar,

7 1997). No mass mortally event has been found to have occurred in the Canary Islands

8 over the last decades (Brito et al., 1984; Lessios, 1988), not even during the early 80s

9 when a huge mortality took place in the western Atlantic and eliminated almost the entire

10 Caribbean Diadema antillarum population (see review in Lessios, 1988). Some factors

11 may have kept the eastern species free of disease. The Atlantic Ocean itself acts as barrier

12 and the two populations have been separate for about 2 million years (Lessios et al.,

13 2001). Moreover, the high urchin density found on the Caribbean before the mortality

14 event (Sammarco, 1982; Bak et al., 1984; Lessios, 1988) and in other areas involving

15 other urchin species (Pearse et al., 1977; Scheibling and Hennigar, 1997) compared to the

16 low densities in barrens of the Canary Islands, lends itself to disease propagation.

17 During 2005 and 2006 an increase in water temperature around the Canaries caused a

18 sudden outbreak in the urchin population by assisting larval settlement (Hernández, 2006;

19 Hernández et al., 2006a); but the effects were clearly variable across the Archipelago.

20 Densities increased after the demographic outbreak in barren areas in Tenerife and at

21 most sites in Lanzarote, except in a no-take area in La Graciosa MPA where lower urchin

22 density and higher non-crustose macroalgal cover were recorded after the outbreak. Due

23 to protection policies introduced at the site 11 years ago, urchin predators are gradually

24 becoming more abundant, which will ultimately help alleviate the barren situation. 
1 Although, this is a seemingly promising result, barren grounds have still persisted at this

2 site. On El Hierro very low urchin densities and high cover of Lobophora were recorded

3 before the outbreak event and no change in urchin density or percentage barren cover was

4 detected. A comparison of this result with the latter, demonstrates that the system's

5 degree of resilience to an outbreak event is dependent on how well structured the system

6 is, which means that no disturbance has altered any trophic levels. El Hierro was well

7 structured before the event, with high macroalgae cover and abundant fish predators

8 (Bortone et al., 1991; Hernández, et al., 2007a), which has provided the island protection

9 against the general trend toward an increase in urchin density.

10 Algal beds have persisted on El Hierro for decades, even before the implementation

11 of the MPA (Brito et al., 1984; Bortone et al., 1991). The Lobophora state seems to act as

12 a buffer against urchin domination trend in the Canary Islands (Hernández, 2006), due

13 either to a well structured system where predators control urchins or simply because

14 Lobophora beds are not suitable for larval settlement or urchin growth. It has been

15 speculated that predation at El Hierro (Bortone et al., 1991; Falcón et al., 1996; Tuya et

16 al., 2004) controls urchin population by 'top down forces', although specific experiments

17 are needed to verify this hypothesis. As noted by Sala (2006) and Guidetti and Sala

18 (2007), a well structured system seems to be resilient as it is shielded from external

19 human impacts and sea water warming (Knowlton, 2004). Lobophora algal beds seem to

20 be resistent to various biotic and abiotic perturbations, a situation comparable to that of

21 kelp in temperate regions (Sutherland, 1981). Additionally, the higher sea water

22 temperatures surrounding the western islands combined with the general increase in

23 temperature detected in the Canary Islands (Hernández, 2006) could be favouring the 
1 development and persistence of the tropical Lobophora variegata beds, by aiding its

2 settlement and growth.

3 In conclusion, Diadema aff. antillarum abundance clearly determines barren grounds

4 distribution and algal beds dominated by Lobophora in the Canary Islands. Extension and

5 persitence of both barrens and algal stands appear to be related to certain environmental

6 factors, as well as to anthropogenic disturbances. The latter points out the importance of

7 protection measures such as MPAs and the need to implement of restrictive fishing

8 policies that help promote healthy systems which in turn control urchin populations.

\section{Acknowledgements}

11 To N. Garcia who helped in data collection. To J.M. Falcon, A. Sancho, G.

12 Gonzalez-Lorenzo and P. Pascual for their incalculable help. To J. Manning who always

13 improves our manuscripts. The F.P.U. fellow program of 'Ministerio de Educacion y

14 Ciencia' supported J.C.H. and S.C. Thanks to 'Viceconsejeria de Medio Ambiente and

15 Viceconsejeria de Pesca del Gobierno de Canarias' for their support.

\section{$17 \quad$ References}

18 Airoldi, L., 2003. The effects of sedimentation on rocky coast assemblages.

19 Oceanography and Marine Biology: An Annual Review, 41, 161-236.

20 Alves, F.M.A., Chícharo, L.M., Serrao, E., Abreu, A.D., 2001. Algal cover and sea 21 urchin spatial distribution at Madeira Island (NE Atlantic). Scientia Marina, 65, 38322392. 
1 Anderson, M.J., 2001. Permutational tests for univariate or multivariate analysis of

2 variance and regression. Canadian Journal of Fisheries and Aquatic Sciences, 58, $3 \quad 626-639$.

4 Andrew, N.L., 1993. Spatial heterogeneity, sea urchin grazing, and habitat structure on 5 reefs in temperate Australia. Ecology, 74, 292-302.

6 Bas, C., Castro, J.J., Hernández-García, V., Lorenzo, J.M., Moreno, T., Pajuelo, J.G., 7 González-Ramos, A.J., 1995. La Pesca en Canarias y Áreas de Influencia. Las Palmas 8 de Gran Canaria: Ediciones del Cabildo Insular de Gran Canaria.

9 Barton, E.D., Aristegui, J., Tett, P., Canton, M., García-Braun, J., Hernández-Leon, S., 10 Nykjaer, L., Almeida, C., Almunia, J., Ballesteros, S., Basterretxea, G., Escánez, J., 11 García-Weill, L., Hernández-Guerra, A., López-Laatzen, F., Molina, R., Montero, 12 M.F., Navarro-Pérez, E., Rodríguez, J.M., van Lenning, K., Veleza, H., Wilda, K., 13 1998. The transition zone of the Canary Current upwelling region. Progress in 14 Ocenography, 41, 455-504.

15 Bak, R.P.M., Carpay, M.J.E., de Ruyter van Steveninck, E.D., 1984. Densities of the sea 16 urchin Diadema antillarum before and after mass mortalities on the coral reefs of 17 Curacao. Marine Ecology Progress Series, 17, 105-8.

18 Bortone, S.A., Tassell, J.V., Brito, A., Falcón, J.M., Bundrick, S.M., (1991). A visual 19 assessment of the inshore fishes and fisheries resources off El Hierro, Canary Islands: 20 a base line survey. Scientia Marina, 55, 529-541.

21 Brito, A., Cruz, T., Moreno, E., Pérez, J.M., 1984. Fauna Marina de las Islas Canarias. In: 22 Bacallado J.J. (Ed.). Fauna marina y terrestre del Archipiélago Canario. Edirca, Las 23 Palmas de Gran Canaria, 42-65 pp. 
1 Brito, A., Falcón, J.M., Aguilar, N., Pascual, P., 2001. Fauna Vertebrada Marina. In:

2 Fernandez-Palacios, J.M., Martín-Esquivel J.L. (Eds.). Naturaleza de las Islas

3 Canarias: Ecología y Conservación. Turquesa Ediciones, Santa Cruz de Tenerife, $4 \quad 219-231 \mathrm{pp}$.

5 Brito, A., Hernández, J.C., Falcón, J.M., García, N., González-Lorenzo, G., Gil-Rodríguez,

6 M.C., Cruz-Reyes, A., Herrera, G., Sancho, A., Clemente, S., Cubero, E., Girard, D.,

7 Barquín, J., 2004. El Erizo de lima (Diadema antillarum) una especie clave en los

8 fondos rocosos litorales de Canarias. Macaronesia, 6, 68-86.

9 Carpenter, R.C., 1981. Grazing by Diadema antillarum (Philippi) and its effects on the 10 benthic algae community. Journal of Marine Research, 39, 749-765.

11 Chapman, A.R.O., 1981. Stability of sea urchin dominated barren grounds following 12 destructive grazing of kelp in St. Margaret's Bay, eastern Canada. Marine Biology, $13 \quad 62,307-311$.

14 Clemente, S., Hernández, J.C., Toledo, K., Brito, A., 2007. Predation upon Diadema aff. 15 antillarum at barrens grounds in the Canary Islands. Scientia Marina, 71, 745-754.

16 Debrot, A.O., Nagelkerken, I., 2006. Recovery of the long-spined sea urchin Diadema 17 antillarum in Curaçao (Netherlands Antilles) linked to lagoonal and wave sheltered 18 shallow rocky habitats. Bulletin of Marine Science, 79, 415-424.

19 Díez, I., Santolaria, A., Gorostiaga, J.M., 2003. The relationship of environmental 20 factors to the structure and distribution of subtidal seaweed vegetation of the western 21 Basque coast (N Spain). Estuarine Coastal and Shelf Science, 56, 1041-1054.

22 Ebert, T.A., 1983. Recruitment in echinoderms. In: Lawrence J.M., Jangoux, M. (Eds.). 23 Echinoderm Studies. Balkema, Rotterdam, 169-203 pp. 
1 Ebert, T.A., Russell, M.P., 1988. Latitudinal variation in size structure of the west coast

2 purple sea urchin: a correlation with headlands. Limnology and Oceanography, 33, $3286-294$.

4 Falcón, J.M., Bortone, S.A., Brito, A., Bundrick, C.M., 1996. Structure of and 5 relationships within and between the littoral, rock-substrate fish communities off four 6 islands in the Canarian Archipelago. Marine Biology, 125, 215-231.

7 Guidetti, P., 2006. Marine reserves reestablish lost predatory interactions and cause 8 community effects in rocky reefs. Ecological Applications, 16, 963-976.

9 Guidetti, P, Sala, E., 2007. Community-wide effects of marine reserves in the 10 Mediterranean Sea. Marine Ecology Progress Series, 335, 43-56.

11 Guidetti, P., Dulčić, J., 2007. Relationship among predatory fish, sea urchins and barrens 12 in Mediterranean rocky reef across a latitudinal gradient. Marine Environmental 13 Research, 63, 168-184.

14 Gratwicke, B., Speight, M.R., 2005. Effects of habitat complexity on Caribbean marine 15 fish assemblages. Marine Ecology Progress Series, 292, 301-310.

16 Harrold, C., Pearse, J.S., 1987. The ecological role of echinoderms in kelp forests. In:

17 Jangoux, M., Lawrence J.M. (Eds.). Echinoderm Studies 2. Balkema, Rotterdam, $18 \quad 137-233 \mathrm{pp}$.

19 Hawkins, J.E., Roberts, C.M., 2004. Effects of artisanal fishing on Caribbean coral reefs. 20 Conservation Biology, 18, 215-226.

21 Hernández, J.C., 2006. Estrategia reproductiva de la población canaria del erizo 22 Diadema aff. antillarum Philippi, 1845: maduración gonadal, asentamiento larvario y 23 reclutamiento. La Laguna: Servicio de Publicaciones de La Universidad de La 24 Laguna. PhD. Thesis. 
1 Hernández, J.C., Clemente, S., Brito, A., 2006a. Effects of seasonality and environmental

2 variables on the reproduction, settlement and recruitment of the sea urchin Diadema

3 aff. antillarum at the Canary Islands. Proceedings of the XII International

4 Echinoderm Conference. University of New Hampshire, Durham NH, USA.

5 Hernández, J.C., Brito, A., Cubero, E., García, N., Girard, D., González-Lorenzo, G.,

6 Falcón, J.M., 2006b. Temporal patterns of larval settlement of Diadema aff.

7 antillarum in the Canary Islands using an experimental larval collector. Bulletin of

$8 \quad$ Marine Science, 78, 271-279.

9 Hernández, J.C., Clemente, S., Sangil, C., Brito, A., 2007a. Actual status of Diadema aff.

10 antillarum populations and macroalgal cover in the Marine Protected Areas

11 comparing to a Highly Fished Area (Canary Islands-Eastern Atlantic Ocean). Aquatic

12 Conservation: Marine and Freshwater Ecosystems. DOI: 10.1002/aqc.903.

13 Hernández, J.C., Gil-Rodriguez, M.C., Herrera-López, G., Brito, A., 2007b. Diet of the

14 "key herbivore" Diadema antillarum in two contrasting habitats in the Canary Islands

15 (Eastern-Atlantic). Vieraea, 35, 109-120.

16 Herrera, R., 1998. Dinámica de las comunidades bentónicas de los arrecifes artificiales de

17 Arguineguín (Gran Canaria) y Lanzarote. Las Palmas de Gran Canaria: Universidad 18 de Las Palmas de Gran Canaria. PhD thesis.

19 Knowlton, N., 2004. Multiple "stable" states and the conservation of marine ecosystems.

20 Progress in Oceanography, 60, 387-396.

21 Lauzon-Guay, J.S., Scheibling, R.E., 2007. Seasonal variation in movement, aggregation

22 and destructive grazing of the green sea urchin (Strongylocentrotus droebachiensis)

23 in relation to wave action and temperature. Marine Biology, 151, 2109-2118. 
1 Lawrence, J.M., 1975. On the relationships between marine plants and sea urchins.

2 Oceanography and Marine Biology: an Annual Review, 13,213-286.

3 Lee, S.C., 2006. Habitat complexity and consumer-mediated positive feedbacks on a $4 \quad$ Caribbean coral reef. Oikos, 112, 442-447.

5 Lessios, H.A., 1988. Mass mortality of Diadema antillarum in the Caribbean: What have

6 we learned? Annual Review of Ecology Evolution and Systematics, 19, 371-379.

7 Lessios, H.A., Kessing, B.D., Pearse, J.S., 2001. Population structure and speciation in

8 tropical seas: global phylogeography of the sea urchin Diadema. Evolution, 55, 9559975.

10 Levitan, D.R., Genovese, S.J., 1989. Substratum-dependent predator-prey dynamics:

11 patch reefs as refuges from gastropod predation. Journal of Experimental Marine

12 Biology and Ecology, 130, 111-118.

13 McClanahan, T.R., 1994. Kenyan coral reef lagoon fish: effects of fishing, substrate 14 complexity, and sea urchins. Coral Reefs, 13, 231-241.

15 North, W.J., Pearse, J.S., 1970. Sea urchin population explosion in southern California 16 Coastal Waters. Science, 167, 209.

17 Ogden, J.C., Brown, R.A., Salesky, N., 1973. Grazing by the echinoid Diadema 18 antillarum Philippi: formation of halos around West Indian path reefs. Science, 182, $19 \quad 715-717$.

20 Pearse, J.S., Hines A.H., 1987. Long-term population dynamics of sea urchins in a central 21 California kelp forest: rare recruitment and rapid decline. Marine Ecology Progress 22 Series, 39, 275-283. 
1 Pearse, J.S., Costa, D.P., Yellin, M.B., Agegian, C.R., 1977. Localized mass mortality of

2 red sea urchin Strongylocentrotus franciscanus, near Santa Cruz, California. Fishery

3 Bulletin, 75, 645-648.

4 Sala, E., 2006. Top predators provide insurance against climate change. Trends in $5 \quad$ Ecology \& Evolution, 21, 479- 480.

6 Sala, E., Bouderesque, C.F., Harmelin-Vivien, M., 1998. Fishing, trophic cascades, and

7 the structure of algal assemblages: evaluation of an old but untested paradigm. Oikos, $8 \quad 82,425-439$.

9 Sammarco, P.W., 1982. Effects of grazing by Diadema antillarum Philippi

10 (Echinodermata: Echinoidea) on algal diversity and community structure. Journal of

11 Experimental Marine Biology and Ecology, 65, 83-105.

12 Sangil, C., Sansón, M., Afonso-Carrillo, J., 2006. Distribución de las comunidades

13 algales de sustratos rocosos en la isla de La Palma (Islas Canarias). Proceedings of the

14 XIV Simposio Ibérico de Estudios en Biología Marina, Universidad Complutense de 15 Barcelona, Barcelona, España.

16 Sansón, M., Reyes, J., Afonso-Carrillo, J., 2001. Flora Marina. In: Fernández-Palacios,

17 J.M., Martín-Esquivel J.L. (Eds.). Naturaleza de las Islas Canarias: Ecologia y

18 Conservación. Turquesa Ediciones, Santa Cruz de Tenerife, 193-199 pp.

19 Scheibling, R.E., Hennigar, A.W., 1997. Recurrent outbreaks of disease in sea urchins

20 Strongylocentrotus droebachiensis along the Atlantic coast of Nova Scotia: Evidence

21 for a link with large-scale meteorologic and oceanographic events. Marine Ecology

22 Progress Series, 152, 155-165.

23 Sutherland, J.P., 1981. The fouling community at Beaufort, North Carolina: a study in

24 stability. American Naturalist, 118, 499-519. 
1 Tuya, F., Haroun, R.J., 2006. Spatial patterns and response to wave exposure of shallow

2 water algae assemblages across the Canarian Archipelago: a multi-scaled approach.

3 Marine Ecology Progress Series, 311, 15-28.

4 Tuya, F., Boyra, A., Sánchez-Jerez, P., Barbera, C., Haroun, R.J., 2004. Relationships

5 between rocky-reef fish assemblages, the sea urchin Diadema antillarum and

6 macroalgae throughout the Canarian Archipelago. Marine Ecology Progress Series, $7 \quad 278,157-169$.

8 Tuya, F., Sánchez-Jerez, P., Haroun, R.J., 2006a. Populations of inshore serranids across

9 the Canarian Archipelago: Relationships with human pressure and implications for

10 conservation. Biological Conservation, 128, 13-24.

11 Tuya, F., Ortega-Borges, L., Del Rosario-Pinilla, A.B., Haroun R.J. 2006b. Spatio-

12 temporal variability in a key herbivore, the long-spined black sea urchin (Diadema

13 antillarum, Echinodermata: Echinoidea) in the Canary Islands. Journal of the Marine

14 Biological Association of the United Kingdom, 86, 791-797.

15 Tuya, F., Cisneros-Aguirre, J., Ortega-Borges L., Haroun, R.J., 2007. Bathimetric 16 segregation of sea urchins on reefs on the Canarian Archipelago: role of flow-induce 17 forces. Estuarine Coastal and Shelf Science, 73, 481-488.

18 Valentine, J.P., Johnson, S.R., 2005. Persistence of sea urchin (Heliocidaris

19 erythrogramma) barrens on the east coast of Tasmania: inhibition of macroalgal 20 recovery in the absence of high densities of sea urchins. Botanica Marina, 48, 106$21 \quad 115$.

22 Yanes, A., Marzol, M.V., Romero C., 2006. Characterization of sea storms along the 23 coast of Tenerife, the Canary Islands. Journal of Coastal Research, 48, 124-128. 
1 Tables and figures captions:

2 Table 1. List of algae species surveyed at the sampling sites in the Canary Islands.

3 Categorized as non-crustose (turf; unbranched erect; branched erect and calcified erect)

4 and crustose macroalgae.

5 Table 2. Results of three ways Permutational ANOVA comparing (A) density

6 (individuals $\mathrm{m}^{-2}$ ) of Diadema aff. antillarum and (B) barren cover (\%) between the 7

7 islands (1. El Hierro; 2. La Palma; 3. La Gomera; 4.Tenerife; 5. Gran Canaria; 6.

8 Fuerteventura; 7. Lanzarote and islets), two different levels of wave exposure (1. high

9 wave exposure; 2. low wave exposure), and 125 sites across the Canarian Archipelago

10 (Table 1 supplementary material).

11 Table 3. Results of three ways Permutational ANOVA comparing (A) density

12 (individuals $\mathrm{m}^{-2}$ ) of Diadema aff. antillarum and (B) barren cover (\%) between the 7

13 islands (1. El Hierro; 2. La Palma; 3. La Gomera; 4. Tenerife; 5. Gran Canaria; 6.

14 Fuerteventura; 7. Lanzarote and islets), four different sedimentation levels $(1=0 ; 2=1$ -

$1510 \% ; 3=10-20 \% ; 4=>20 \%$ ), and 125 sites across the Canarian Archipelago (Table 1

16 supplementary material).

17 Table 4. Results of three ways Permutational ANOVA comparing (A) density

18 (individuals $\mathrm{m}^{-2}$ ) of Diadema aff. antillarum and (B) barren cover (\%) between the 7

19 islands (1. El Hierro; 2. La Palma; 3. La Gomera; 4. Tenerife; 5. Gran Canaria; 6.

20 Fuerteventura; 7. Lanzarote and islets), four different topographic relief level (1= flat; $2=$

$21<1 \mathrm{~m} ; 3=1-3 \mathrm{~m} ; 4=$ high relief), and 125 sites of the Canarian Archipelago (Table 1

22 supplementary material).

23 Table 5. Diadema aff. antillarum. Summary of the factorial two ways Permutational

24 ANOVA to assess significant differences in (A) abundance of adult D. aff. antillarum 
1 individuals; and (B) percentage barren cover between sampling years $(\mathrm{Y})$ and sites (S:

2 Abades, Boca Cangrejo and Masca) surveyed from 2002 to 2006 and their interactions.

3 Table 6. Results of three ways Permutational ANOVA comparing (A) density

4 (individuals $\mathrm{m}^{-2}$ ) of Diadema aff. antillarum and (B) barren cover (\%) before and after an

5 outbreak event and between three areas (1: El Hierro-MPA (Marine Protected Areas); 2:

6 Tenerife-HFA (Highly Fished Areas); 3: La Graciosa-MPA) and 24 sites of the Canarian

7 Archipelago (Table 1 supplementary material).

9 Figure 1. Study sites across the Canary Islands including Marine Protected Areas

10 (MPAs). Numbers correspond to the different sites listed in table 1 (supplementary

11 material). [Mar Calmas- MPA from 6 to14; La Palma-MPA from 28 to 37; La Graciosa-

12 MPA from 119 to 125$]$.

13 Figure 2. Log-linear relationship between sea urchin (Diadema aff. antillarum)

14 abundance and macroalgal cover.

15 Figure 3. (A1) Comparison of mean sea urchin (Diadema aff. antillarum) abundance ( \pm

$16 \mathrm{SE}$ ) at different wave exposure and (A2) among Islands. (B) Comparison of mean

17 percentage barren cover ( \pm SE) among Island. There was no significant difference

18 between means with identical letters (pairwise analysis). $*=p<0.05 ; * *=p<0.01$.

19 Figure 4. (A) Log-linear relationship between number of islanders per coastal perimeter

20 and sea urchin (Diadema aff. antillarum) abundance. (B) Linear relationship between

21 number of tourists per coastal perimeter and sea urchin abundance. (C) Log-linear

22 relationship between number of fishing boats and sea urchin abundance. [H: El Hierro; P:

23 La Palma; G: La Gomera; T: Tenerife; GC: Gran Canaria; F: Fuerteventura; L: Lanzarote 
1 e islotes]. GC was not included in the analysis as sampled sites were all in close

2 proximity and therefore did not represent the total coastal perimeter.

3 Figure 5. Dispersion diagrams illustrating abundance of Diadema aff. antillarum in the

4 depth range studied $(0.5-25 \mathrm{~m})$, in conditions of high and low wave exposure. Dashed

5 lines shows start depth of urchin barrens. Curved line shows depth range where the

6 maximum abundances of urchins were found.

7 Figure 6. Effects of two habitat complexity variables (A: sedimentation, B: topographic

8 relief) on mean ( \pm SE) abundance of Diadema aff. antillarum and percentage barren

9 cover. Data were analysed using Permutational Anova. There was no significant

10 difference between means with identical letters (pairwise analysis). ns: not significant. *

$11=\mathrm{p}<0.05 ; * *=\mathrm{p}<0.01$

12 Figure 7. Five years monthly temporal variation in (A) mean adult urchin (Diadema aff.

13 antillarum) abundance ( \pm SE); and (B) mean barren cover $( \pm$ SE), in three sites of

14 Tenerife Island (Masca, Abades and Boca Cangrejo).

15 Figure 8. Effects of a massive recruitment event on (A) mean ( \pm SE) Diadema aff.

16 antillarum abundance; (B) barren cover, in three areas of the Canary Islands from west to

17 east (Mar de las Calmas-MPA; Tenerife-HFA (Highly Fished Areas); La Graciosa-MPA).

18 Data were analysed using Permutational Anova.

19 Figure 9. Diadema aff. antillarum general log-linear increment of populations density

20 after a high recruitment event, as a function of initial density registered at HFA and MPA

21 sites throughout the Canarian Archipelago. H: Mar Calmas MPA, RE: Roque del Este site

22 located on La Graciosa-MPA. 
Figure 1

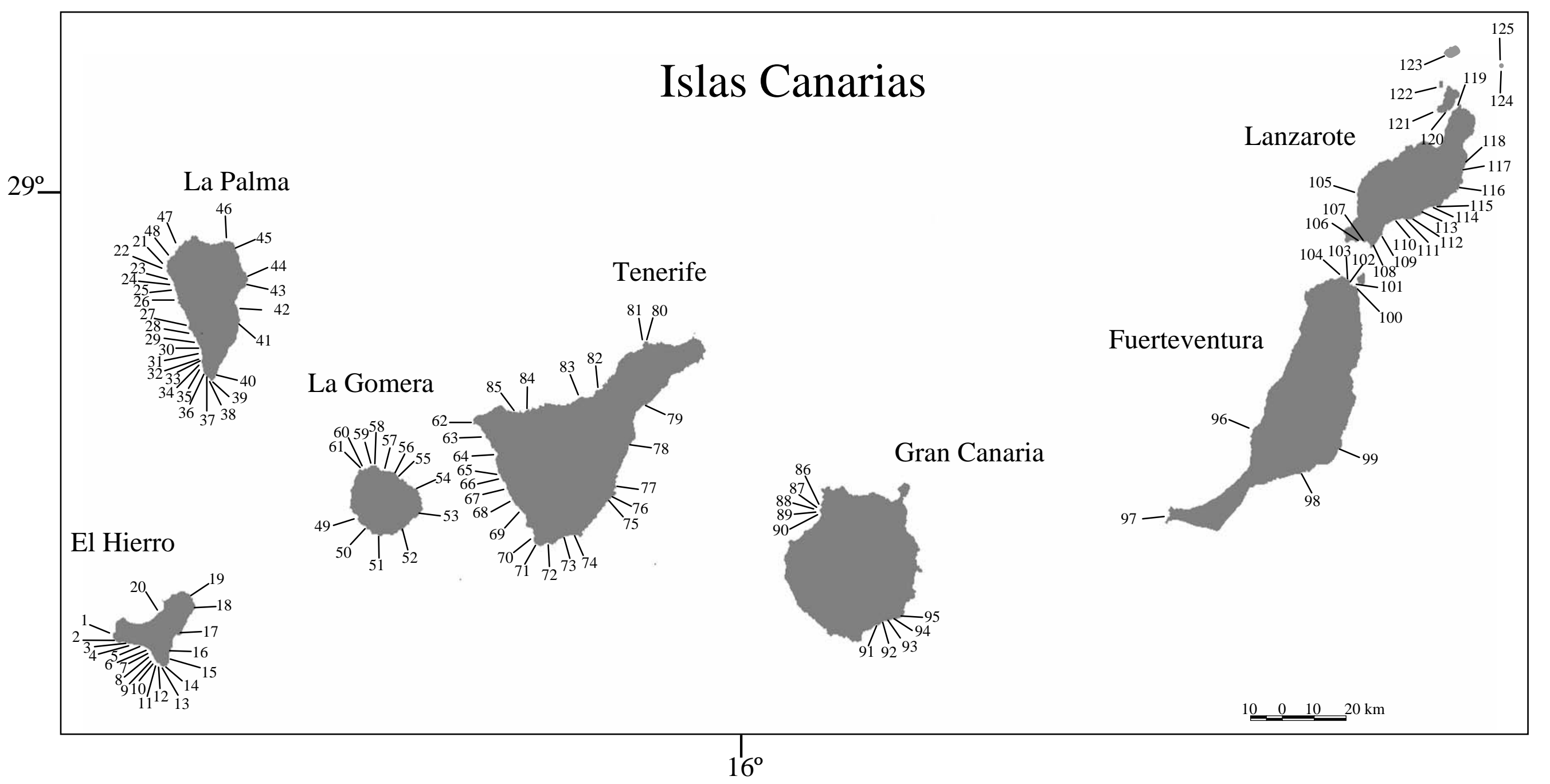


Figure 2

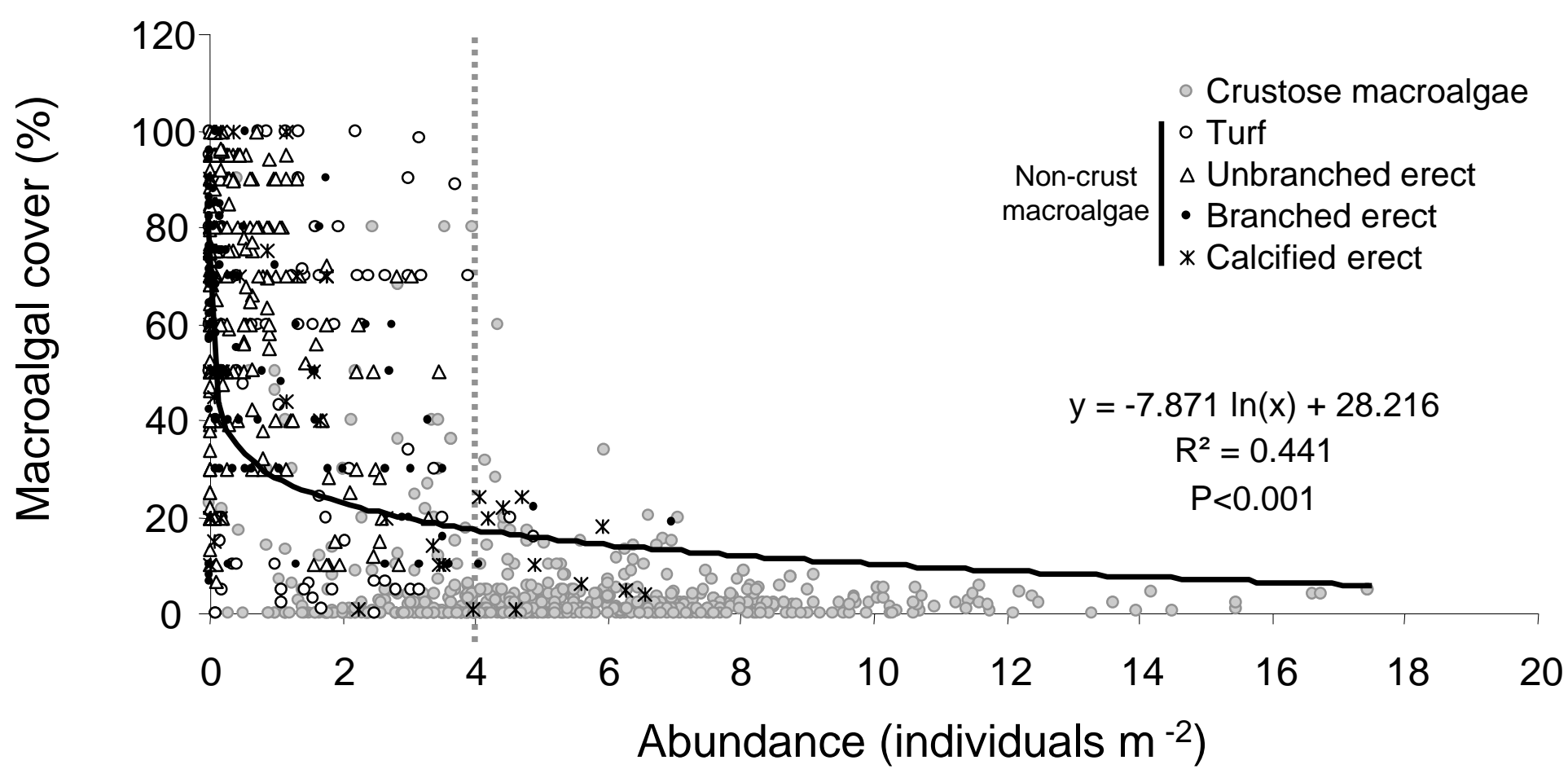



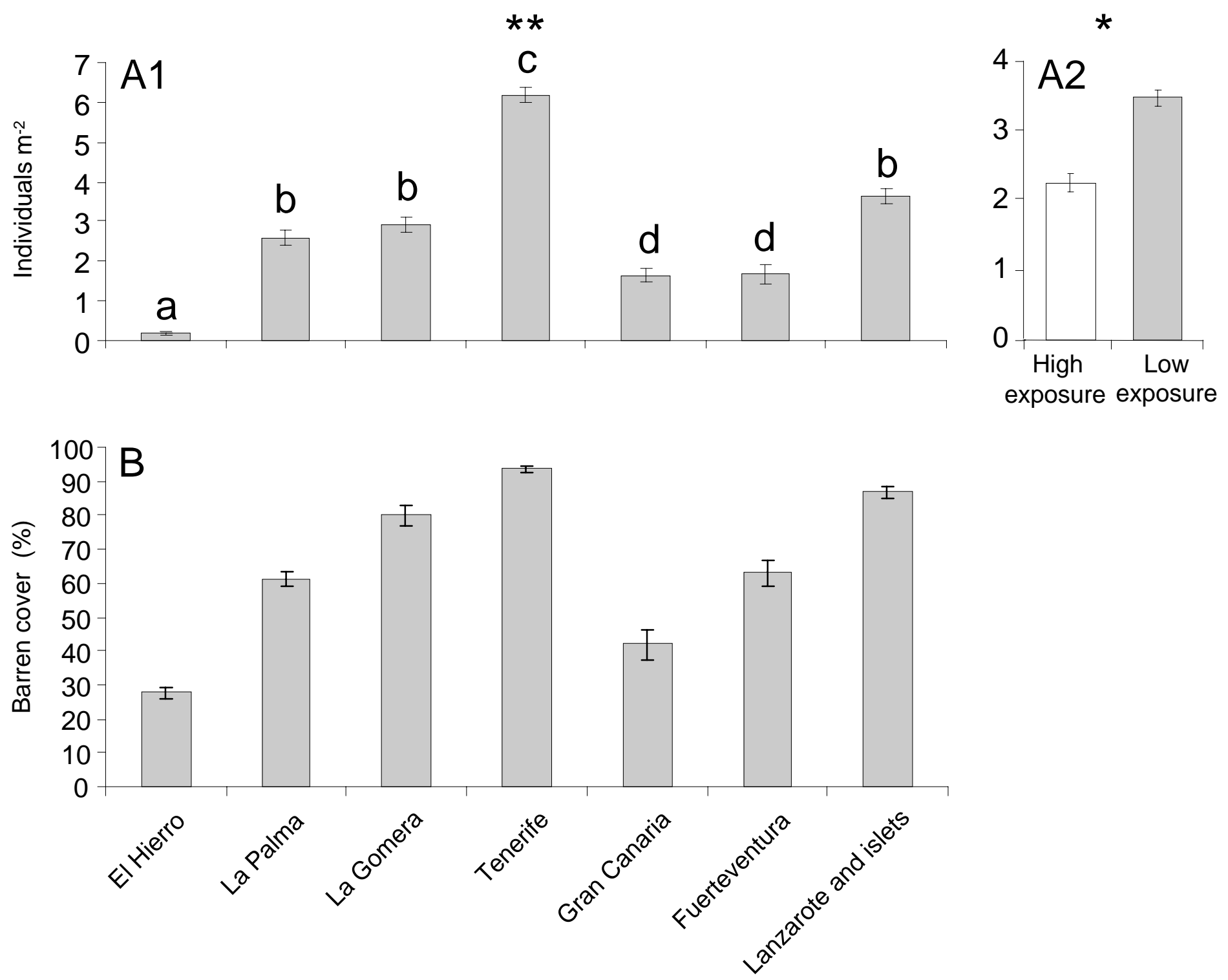

Figure 3 
Figure 4

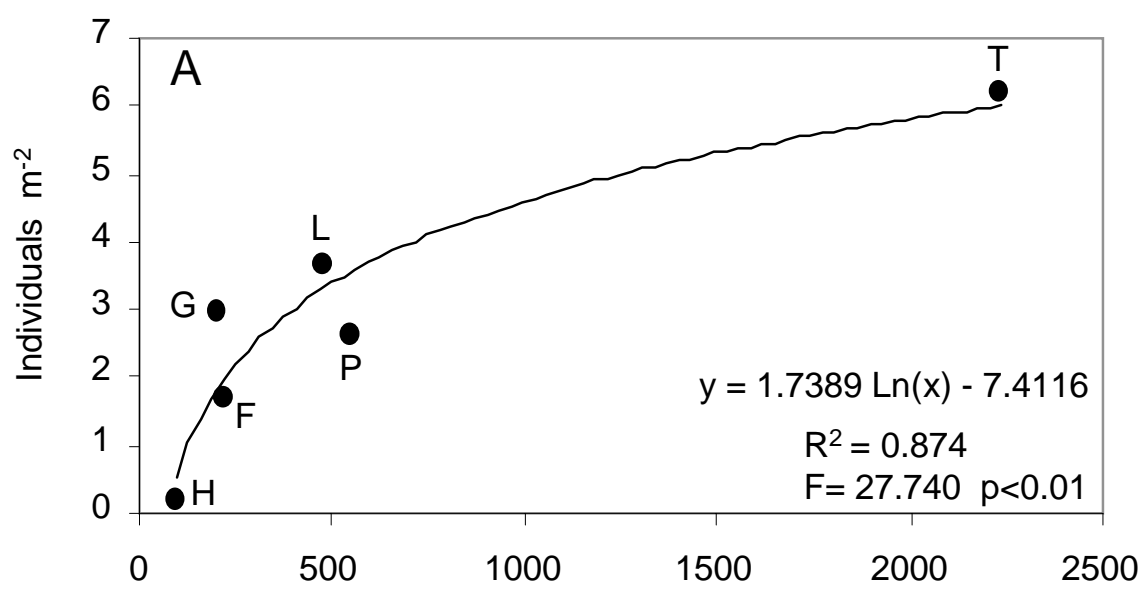

Number of islanders per coastal perimeter

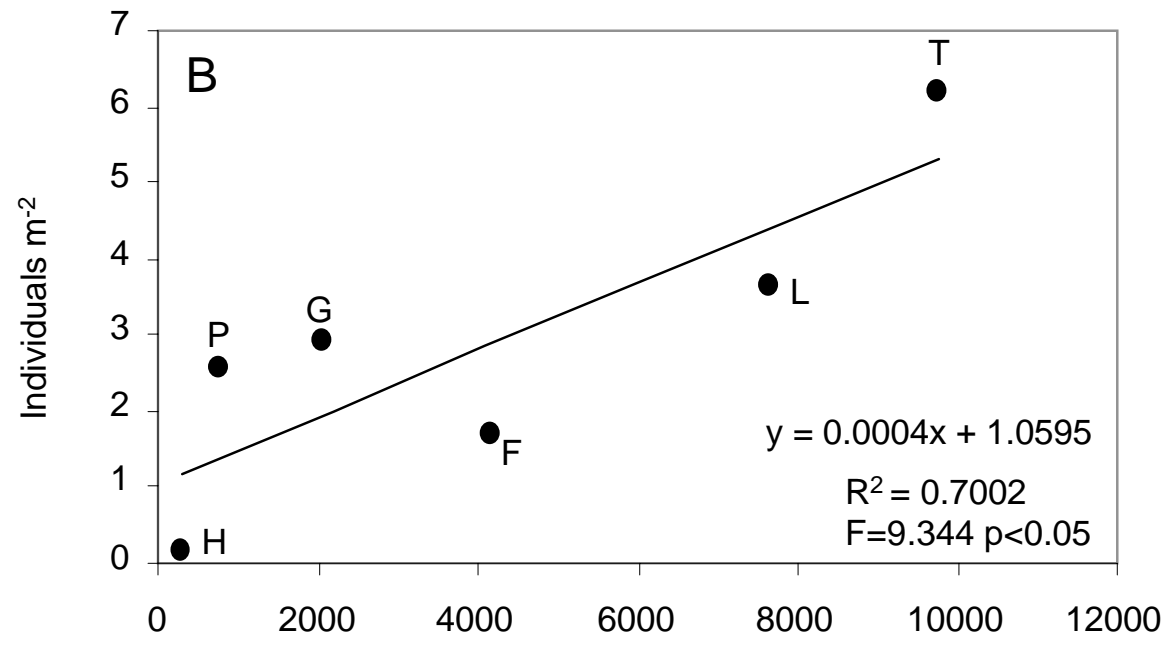

Number of tourist per coastal perimeter

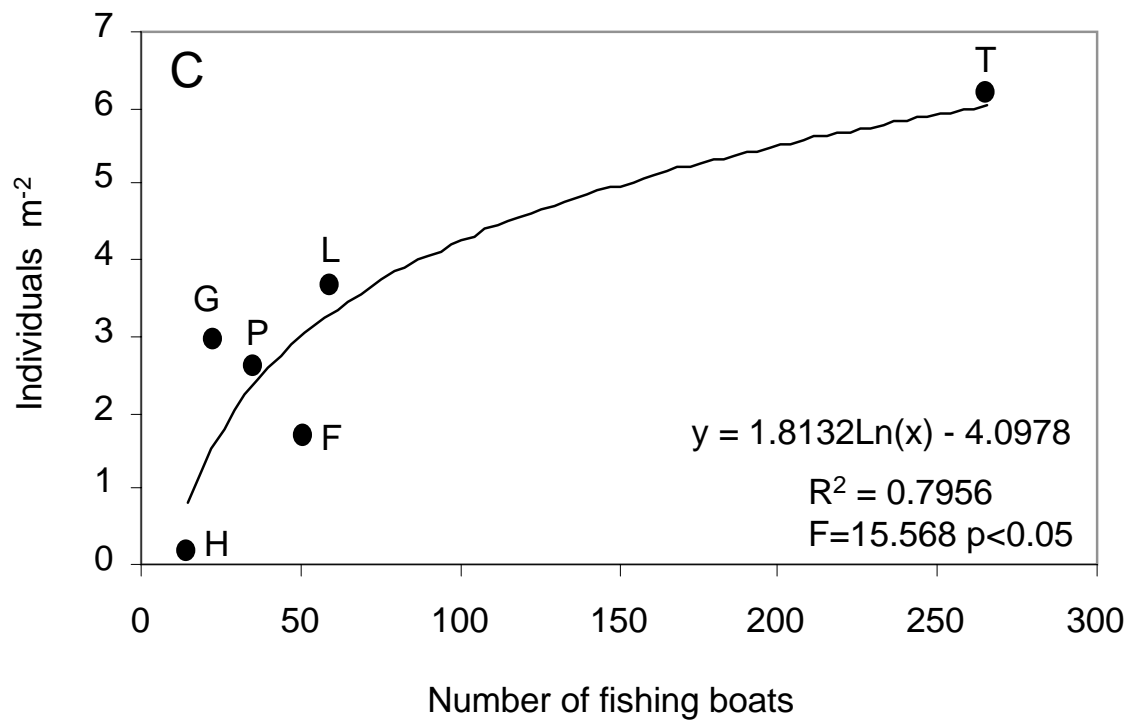


Figure 5

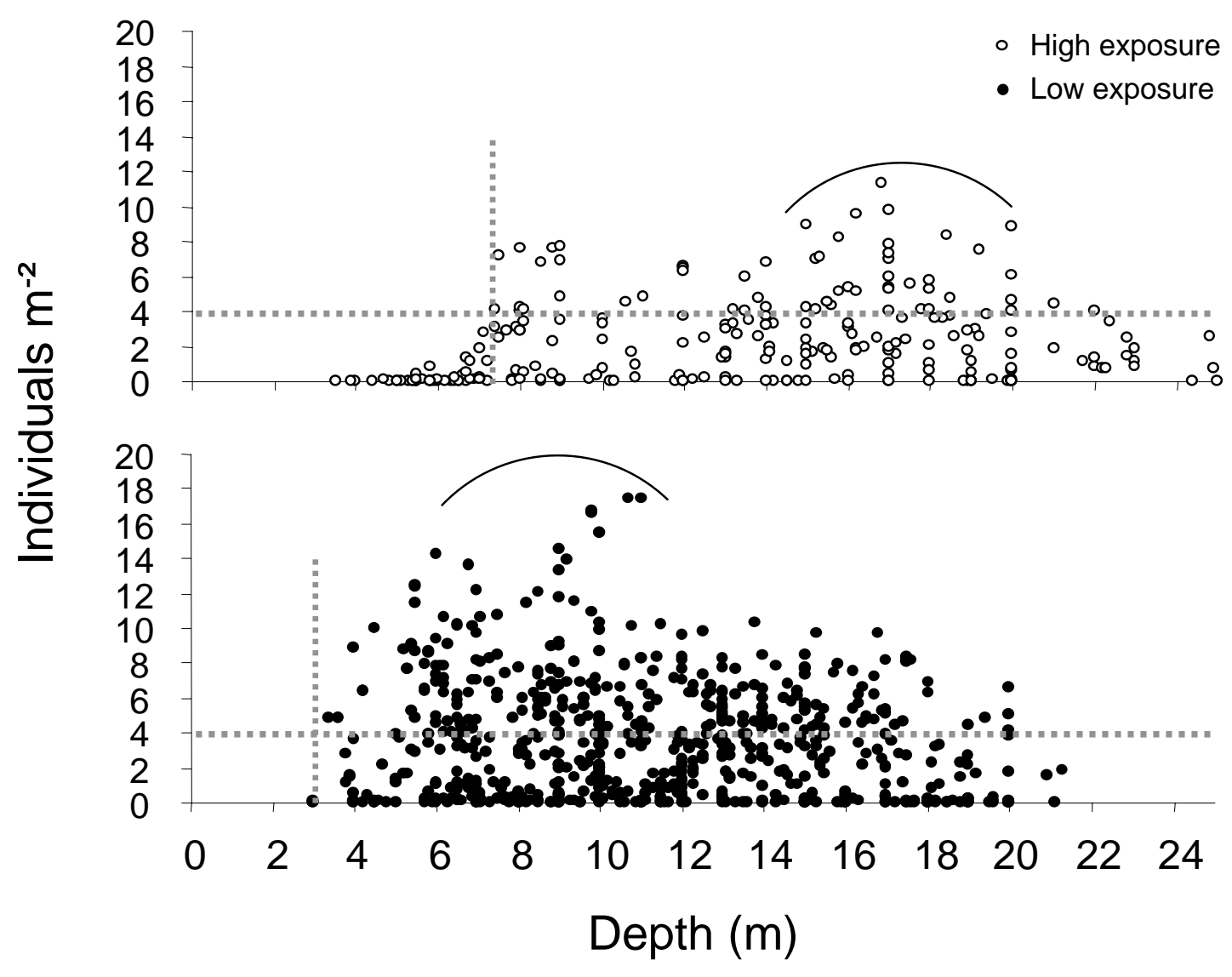


Figure 6
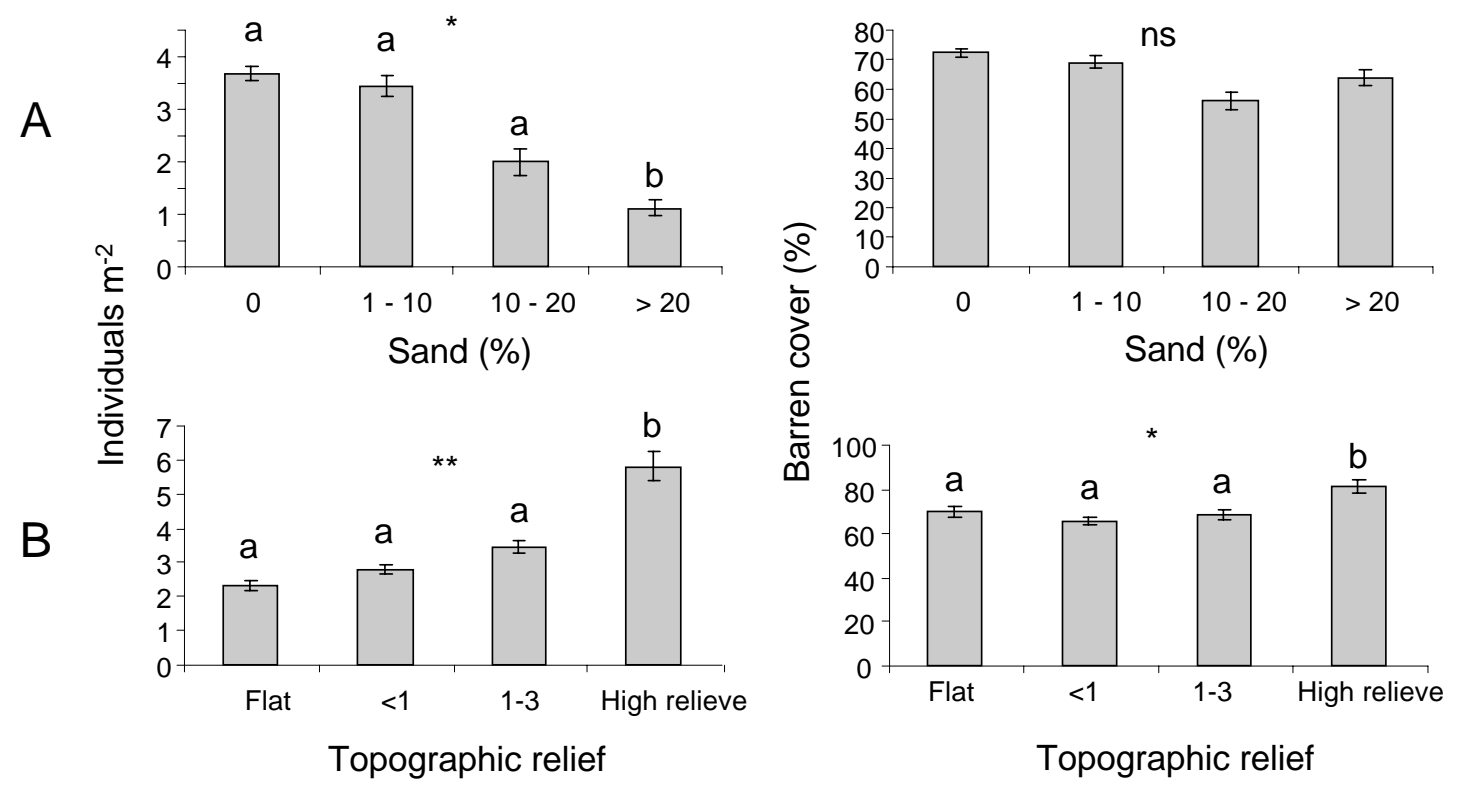


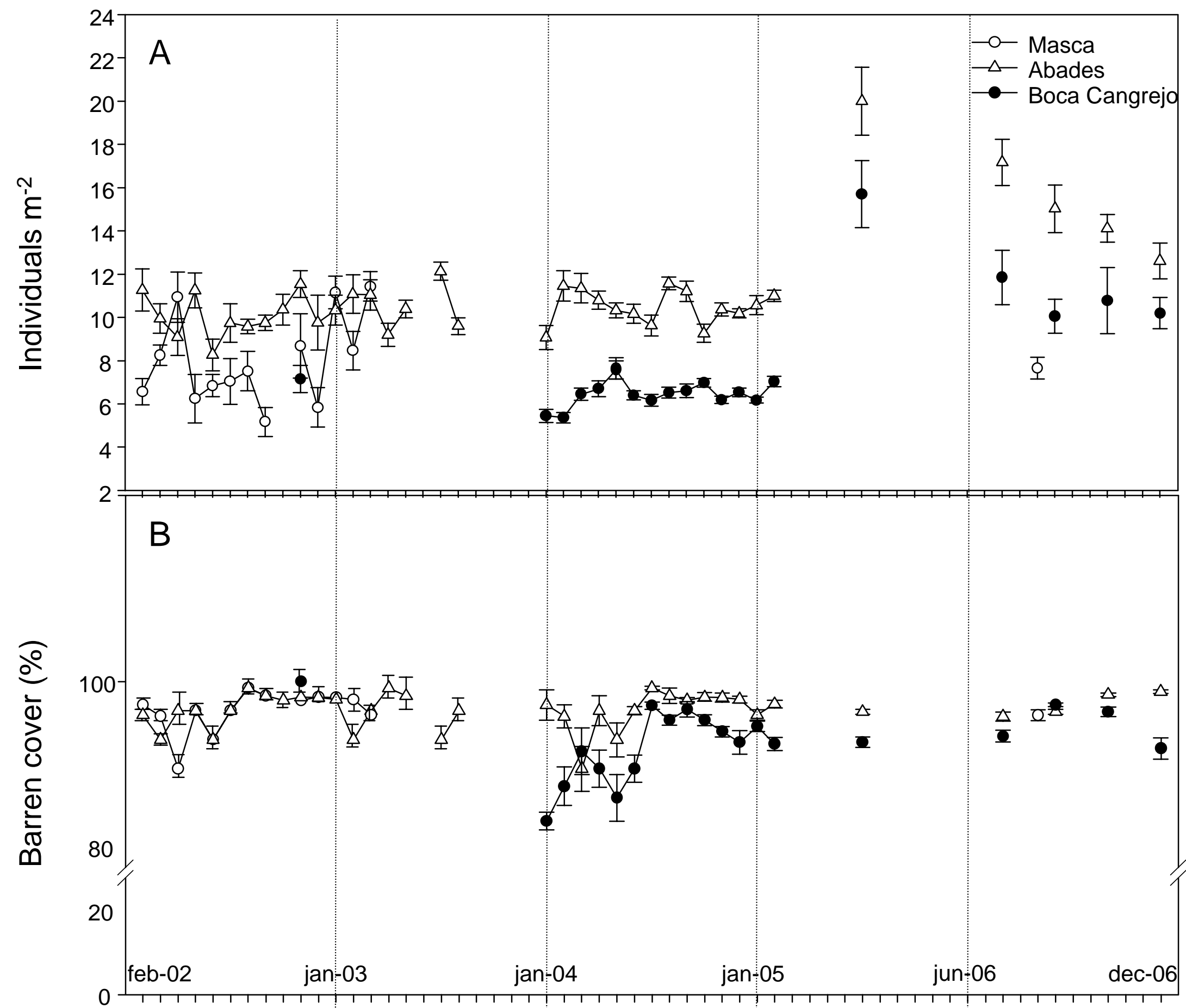

Figure 7 
Figure 8
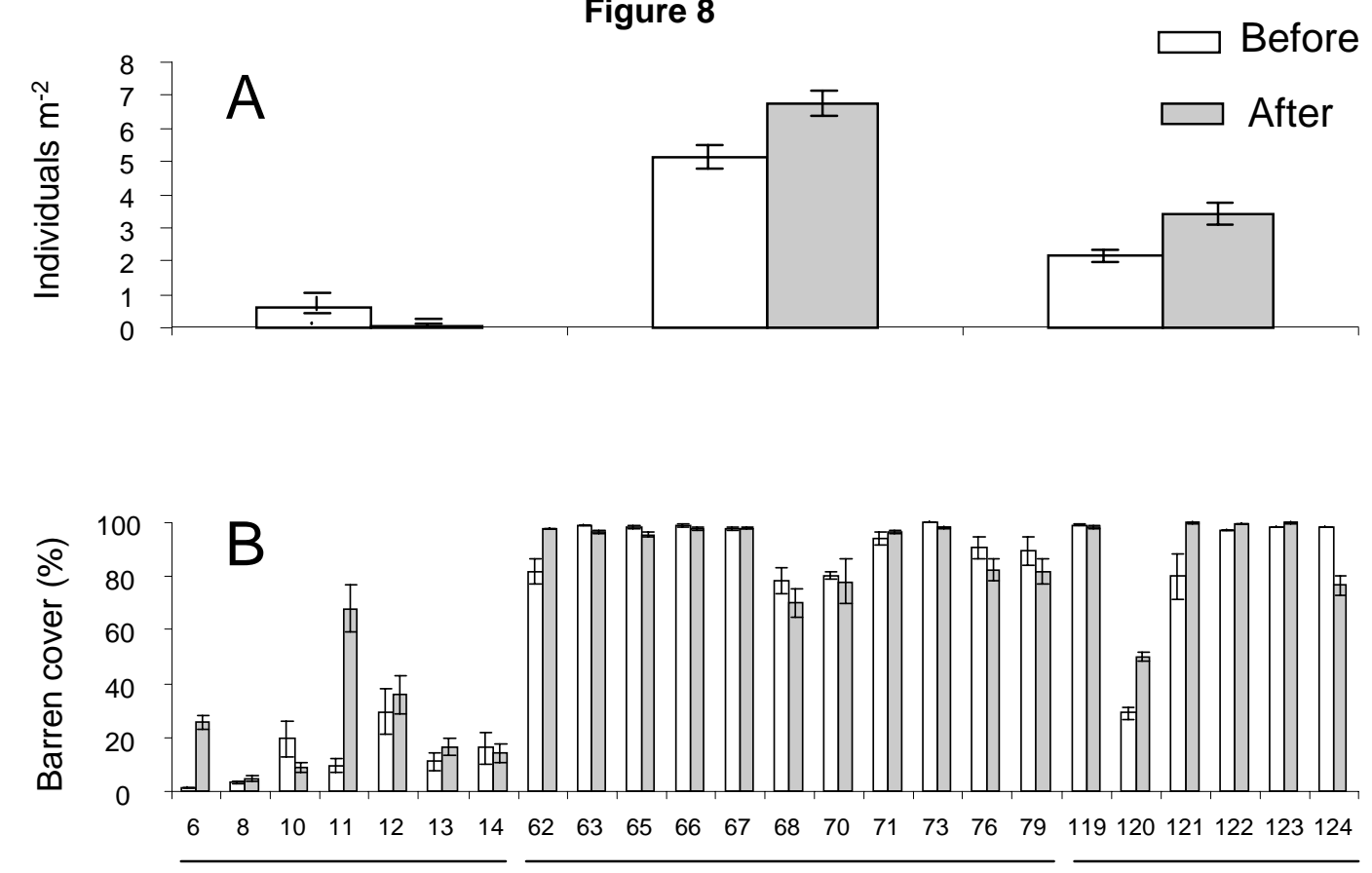

Mar de Las Calmas MPA

(El Hierro)

Tenerife HFA

La Graciosa MPA

(Lanzarote and northern islets) 
Figure 9

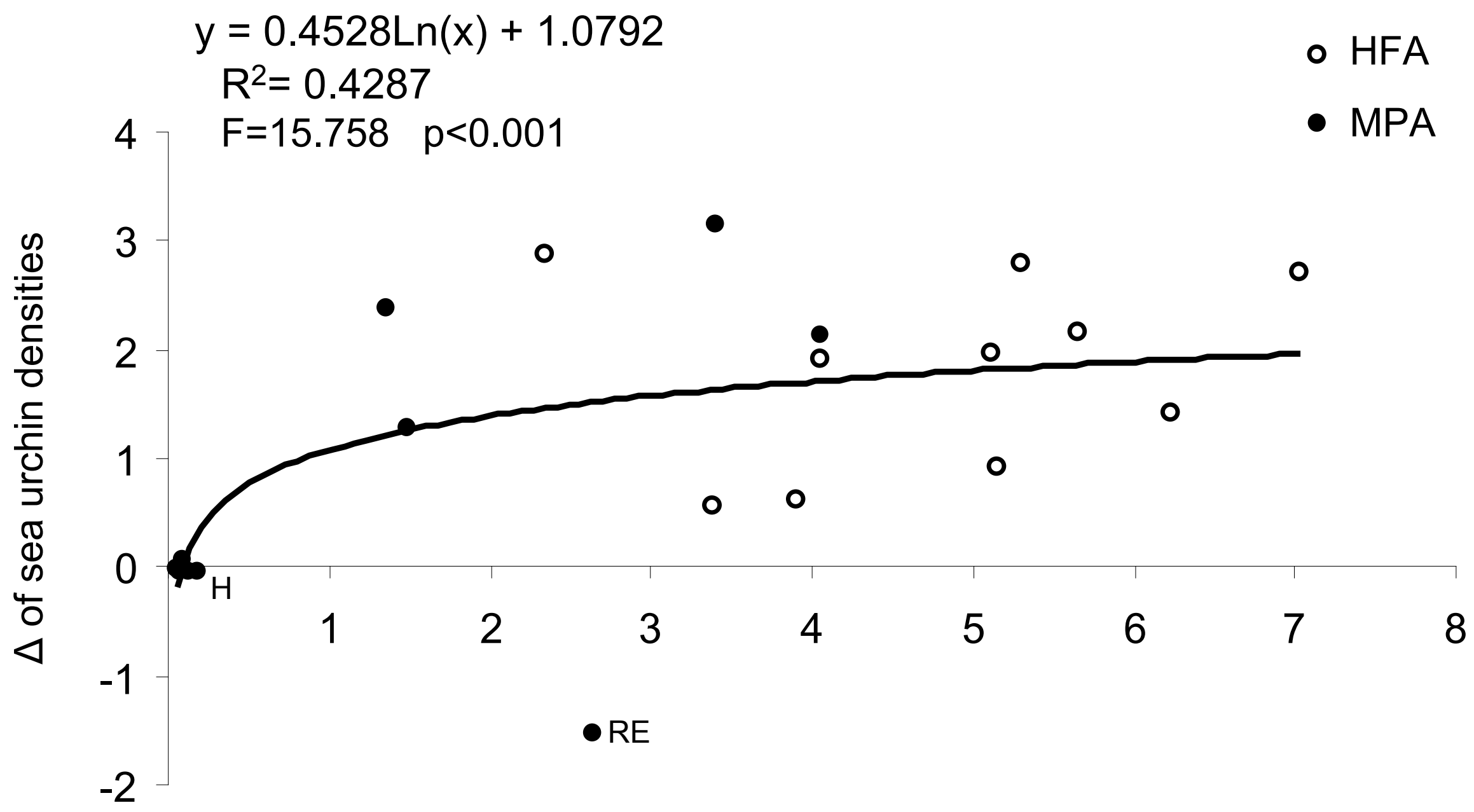

Initial number of $D$. aff. antillarum $\mathrm{m}^{-2}$ 


\section{Table 1}

\begin{tabular}{|c|c|c|c|}
\hline \multicolumn{4}{|c|}{ Non-crustose macroalgae } \\
\hline Turf & Unbranched erect & Branched erect & Calcified erect \\
\hline Amphiroa spp. & Colpomenia sinuosa & Asparagopsis taxiformis & Corallina elongata \\
\hline $\begin{array}{l}\text { Asparagopsis taxiformis } \\
\text { (tetrasporofite) }\end{array}$ & Hydroclathrus clathratus & Cystoseira abies-marina & Liagora ceranoides \\
\hline Ceramium echionotum & Lobophora variegata & Cystoseira compressa & Liagora tetrasporifera \\
\hline Cottoniella filamentosa & Padina pavonica & Cystoseira foeniculacea & \\
\hline Cyanobacteria (unidentified) & & Cystoseira sp. & \\
\hline Caulerpa webbiana & & Dasya baillouviana & \\
\hline Filaments (unidentified) & & Dictyota cervicornis & \\
\hline Gelidiopsis intricata & & Dictyota crenulata & \\
\hline Herposiphonia secunda & & Dictyota dichotoma & \\
\hline Jania adhaerens & & Dictyota fasciola & \\
\hline Jania pumila & & Dictyota pfaffii & \\
\hline Lophocladia trichoclados & & Dictyota sp1. & \\
\hline Polysiphonia furcellata & & Dictyota sp2. & \\
\hline Psedochlorodesmis furcellata & & Galaxaura rugosa & \\
\hline Pseodotetraspora marina & & Hypnea spinella & \\
\hline Sphacelaria cirrosa & & Laurencia spp. & \\
\hline Spyridia hypnoides & & Pterosiphonia pennata & \\
\hline Wrangelia penicillata & & Sargassum desfontainesii & \\
\hline & & Sargassum sp. & \\
\hline & & Stypocaulon scoparium & \\
\hline Crustose macroalgae & & secta & \\
\hline Crutose coralline algae (unidentified) & & & \\
\hline Lithothamnium coralloides & & & \\
\hline Mesophyllum canariense & & & \\
\hline Pseudolithoderma adriaticum & & & \\
\hline
\end{tabular}


Table 2

\begin{tabular}{lllll}
\hline A. Density & df & MS & F & P (perm) \\
\hline Island (I) & 6 & 405.46 & 12.15 & 0.001 \\
Wave exposure (E) & 1 & 131.42 & 4.10 & 0.040 \\
I x E & 6 & 28.63 & 0.86 & 0.545 \\
Site (I x E) & 111 & 37.19 & 18.31 & 0.001 \\
Residual & 987 & 2.03 & & \\
Total & 1111 & & & \\
\hline B. Barren & & & & \\
\hline I & 6 & 66881 & 18.24 & 0.001 \\
E & 1 & 5203.10 & 0.70 & 0.422 \\
I x E & 6 & 8521.40 & 2.32 & 0.038 \\
Site (I x E) & 111 & 4087.80 & 18.94 & 0.001 \\
Residual & 987 & 215.80 & & \\
Total & 1111 & & & \\
\hline
\end{tabular}


Table 3

\begin{tabular}{lllll}
\hline A. Density & df & MS & F & P (perm) \\
\hline Island (I) & 6 & 246.06 & 19.82 & 0.001 \\
Sand (Sa) & 3 & 36.25 & 2.89 & 0.029 \\
I x Sa & 18 & 11.209 & 0.85 & 0.631 \\
Site (I x Sa) & 237 & 19.941 & 12.96 & 0.001 \\
Residual & 847 & 1.5387 & & \\
Total & 1111 & & & \\
\hline B. Barren & & & & \\
\hline I & 6 & 52668 & 41.69 & 0.001 \\
Sa & 3 & 1783.8 & 1.40 & 0.235 \\
I x Sa & 18 & 1993.5 & 1.49 & 0.07 \\
Site (I x Sa) & 237 & 2002.6 & 10.24 & 0.001 \\
Residual & 847 & 195.5 & & \\
Total & 1111 & & & \\
\hline
\end{tabular}


ACCEPTED MANUSCRIPT

Table 4

\begin{tabular}{lllll}
\hline A. Density & df & MS & F & P (perm) \\
\hline Island (I) & 6 & 389.35 & 35.92 & 0.001 \\
Topographic relief (TR) & 3 & 110.70 & 10.30 & 0.001 \\
I x TR & 18 & 14.45 & 1.24 & 0.214 \\
Site (I x TR) & 251 & 16.16 & 10.77 & 0.001 \\
Residual & 833 & 1.50 & & \\
Total & 1111 & & & \\
\hline B. Barren & & & & \\
\hline I & 6 & 47084 & 33.93 & 0.001 \\
TR & 3 & 4182.5 & 3.04 & 0.03 \\
I x TR & 18 & 1183.1 & 0.79 & 0.707 \\
Site (I x TR) & 251 & 2065.3 & 10.46 & 0.001 \\
Residual & 833 & 197.39 & & \\
Total & 1111 & & & \\
\hline
\end{tabular}


Table 5

\begin{tabular}{lllll}
\hline A. Density & df & MS & F & P (perm) \\
\hline Year $(Y)$ & 3 & 414.14 & 48.97 & 0.005 \\
Site $(\mathrm{S})$ & 1 & 710.18 & 96.26 & 0.001 \\
Y x S & 3 & 8.45 & 1.15 & 0.321 \\
Residual & 434 & 7.38 & & \\
Total & 441 & & & \\
\hline B. Barren & & & & \\
\hline Year (Y) & 3 & 166.55 & 1.46 & 0.370 \\
Site (S) & 1 & 189.67 & 13.48 & 0.003 \\
Y x S & 3 & 113.84 & 8.09 & 0.001 \\
Residual & 434 & 14.071 & & \\
Total & 441 & & & \\
\hline
\end{tabular}




\section{ACCEPTED MANUSCRIPT}

Table 6

\begin{tabular}{lllll}
\hline A. Density & df & MS & F & P (perm) \\
\hline Outbreak (O) & 1 & 90.06 & 3.62 & 0.160 \\
Area (A) & 2 & 1330 & 33.79 & 0.001 \\
Site (A) & 21 & 40.58 & 8.27 & 0.001 \\
Ox A & 2 & 25.31 & 3.95 & 0.033 \\
Ox Site (A) & 21 & 6.47 & 1.32 & 0.139 \\
Residual & 451 & 4.90 & & \\
Total & 498 & & & \\
\hline B. Barren & & & & \\
\hline Outbreak (O) & 1 & 1827.10 & 0.87 & 0.441 \\
Area (A) & 2 & $2.4613 \mathrm{E} 5$ & 61.49 & 0.001 \\
Site (A) & 21 & 4138.60 & 24.96 & 0.001 \\
Ox A & 2 & 2121 & 1.78 & 0.218 \\
Ox Site (A) & 21 & 1227.20 & 7.40 & 0.001 \\
Residual & 451 & 165.81 & & \\
Total & 498 & & & \\
\hline
\end{tabular}




\section{ACCEPTED MANUSCRIPT}

\section{Tables supplementary material}

Table 1. List of the surveyed sites in the Canary Islands. [Wave exposure: 1 = highly exposed sites, always affected by waves and swell (NE-NNE) and periodically exposed to NNW swells; 2 = lesser exposed sites or those exposed only to NNE waves]. At least $200 \mathrm{~m}^{2}$ of area sampled at each site. All sites were used in the analysis of small and large scale spatial variation. [* Sites used for long-term monitoring; † Sites used for recent outbreak analysis; $\mathrm{N}$ : total of transect at each sampling time].

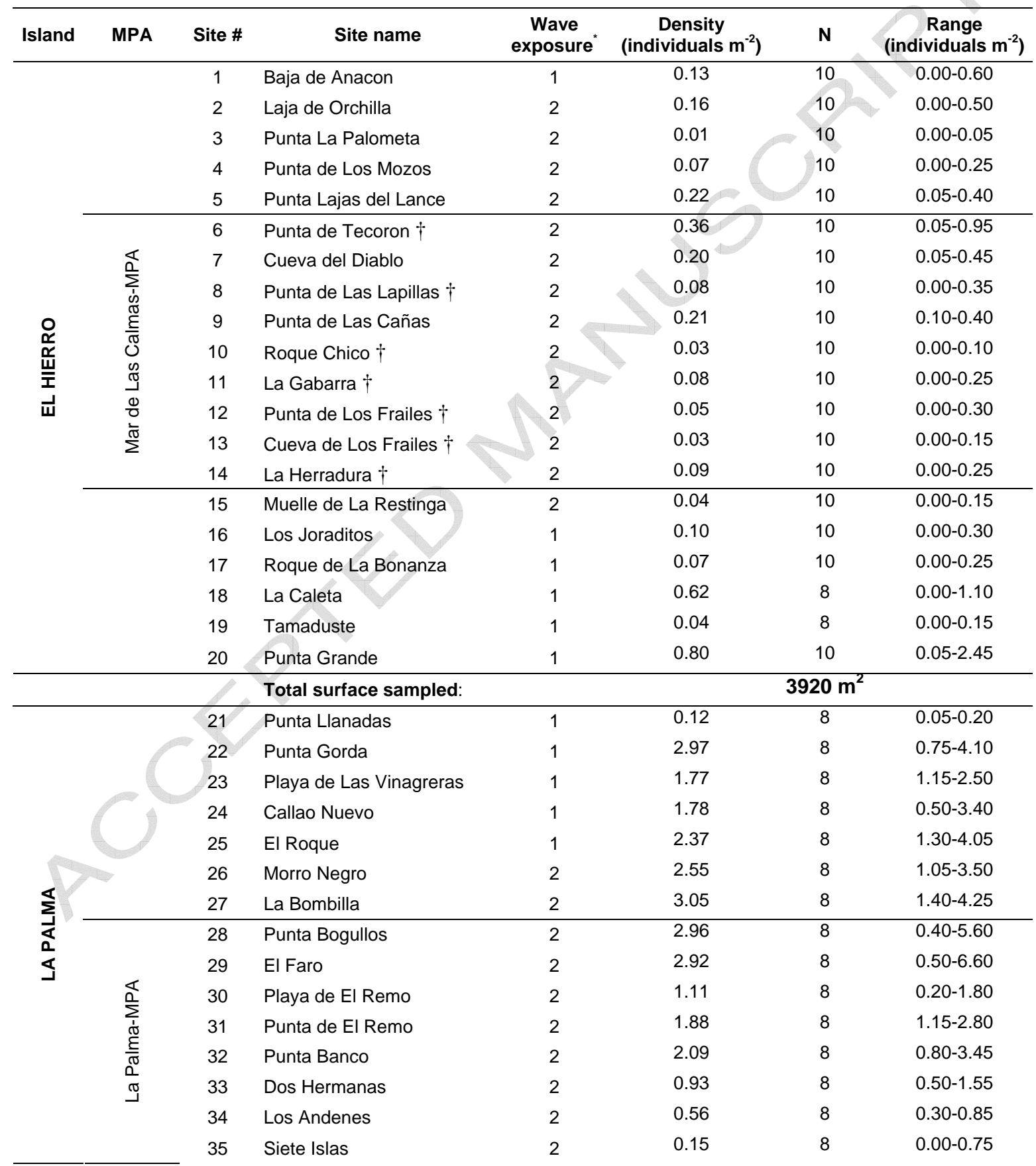


ACCEPTED MANUSCRIPT

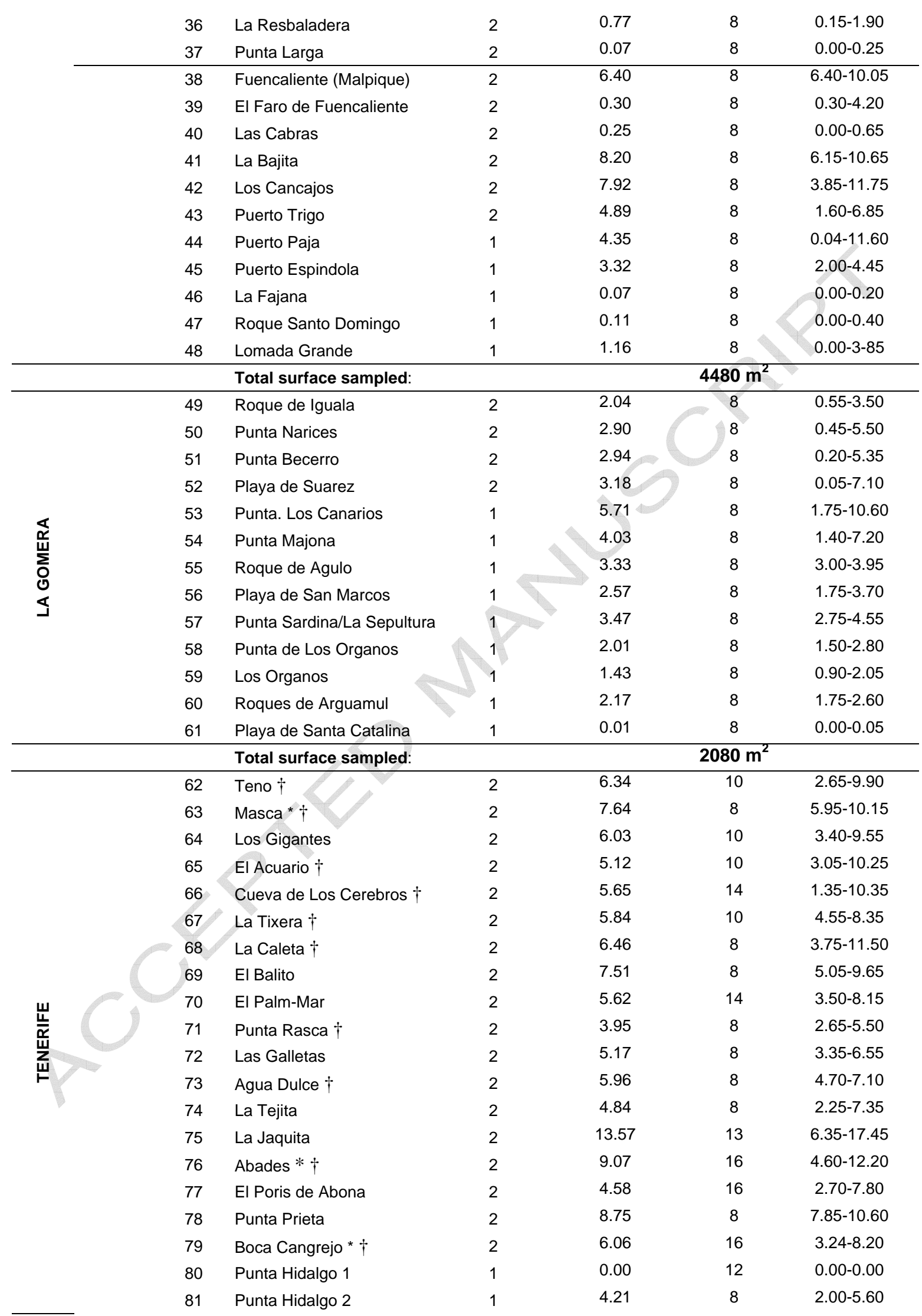




\section{ACCEPTED MANUSCRIPT}

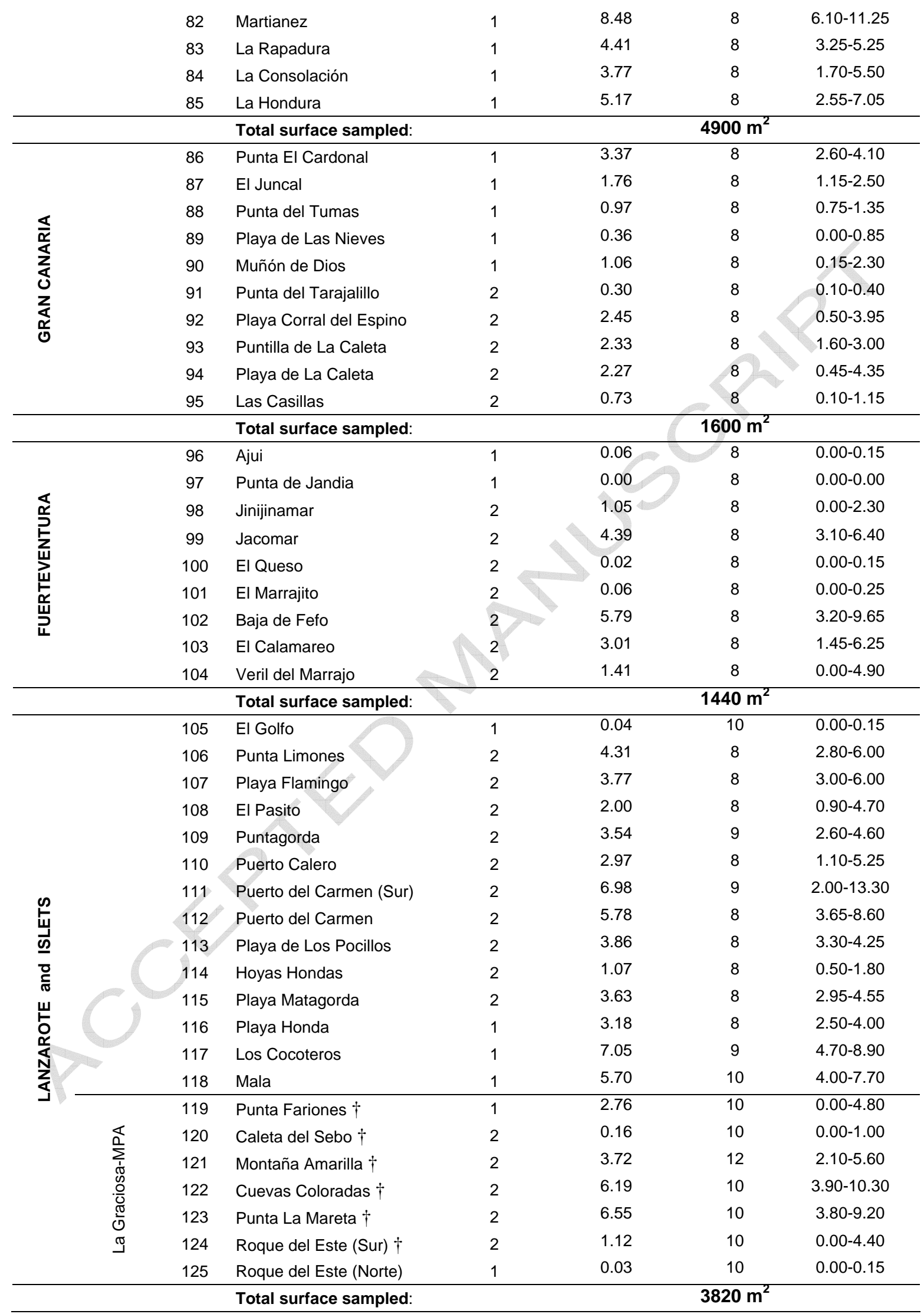




\section{ACCEPTED MANUSCRIPT}

Table 2. Results of three ways Permutational ANOVA designs comparing (A) density (individuals $\mathrm{m}^{-2}$ ) of Diadema aff. antillarum and (B) barren cover (\%) between the 7 islands (1. El Hierro; 2. La Palma; 3. La Gomera; 4. Tenerife; 5. Gran Canaria; 6. Fuerteventura; 7. Lanzarote and islets), four different substrate slopes $\left(1=0^{\circ} ; 2=0-45^{\circ} ; 3=>45^{\circ} ; 4=90^{\circ}\right)$, and 125 sites across the Canarian Archipelago (Table 1 supplementary material).

\begin{tabular}{lllll}
\hline A. Density & df & MS & F & P (perm) \\
\hline Island (I) & 6 & 218.8 & 15.69 & 0.001 \\
Slope (SI) & 3 & 2.896 & 0.20 & 0.891 \\
I x SI & 18 & 6.089 & 0.39 & 0.989 \\
Site (I x SI) & 222 & 21.486 & 12.51 & 0.001 \\
Residual & 862 & 1.717 & & \\
Total & 1111 & & & \\
\hline B. Barren & & & & \\
\hline I & 6 & 37744 & 24.54 & 0.001 \\
SI & 3 & 3817.20 & 2.39 & 0.066 \\
I x SI & 18 & 2232.70 & 1.31 & 0.177 \\
Site (I x SI) & 222 & 2376 & 13.19 & 0.001 \\
Residual & 862 & 180.13 & & \\
Total & 1111 & & & \\
\hline
\end{tabular}


Table 3. Results of three ways Permutational ANOVA designs comparing (A) density (individuals $\mathrm{m}^{-2}$ ) of Diadema aff. antillarum and (B) barren cover (\%) between the 7 islands (1. El Hierro; 2. La Palma; 3. La Gomera; 4. Tenerife; 5. Gran Canaria; 6. Fuerteventura; 7. Lanzarote and islets), three different substrate types ( 1 = bed rock; $2=$ boulders; $3=$ bed rock and boulders), and 125 sites across the Canarian Archipelago (Table 1 supplementary material).

\begin{tabular}{lllll}
\hline A. Density & df & MS & F & P (perm) \\
\hline Island (I) & 6 & 152.45 & 10.12 & 0.001 \\
Substrate diversity (D) & 2 & 1.54 & 0.10 & 0.908 \\
I x D & 12 & 14.49 & 0.88 & 0.540 \\
Site (I x D) & 170 & 26.35 & 13.93 & 0.001 \\
Residual & 921 & 1.89 & & \\
Total & 1111 & & & \\
\hline B. Barren & & & & \\
\hline I & 6 & 25036 & 14.47 & 0.001 \\
D & 2 & 292.11 & 0.17 & 0.844 \\
I x D & 12 & 1810.70 & 0.96 & 0.467 \\
Site (I x D) & 170 & 3041.50 & 15.45 & 0.001 \\
Residual & 921 & 196.90 & & \\
Total & 1111 & & & \\
\hline
\end{tabular}

